\title{
Hydrologic vulnerability to climate change of the Mandrone glacier (Adamello-Presanella group, Italian Alps)
}

\author{
Giovanna Grossi*, Paolo Caronna, Roberto Ranzi \\ DICATAM - Dipartimento di Ingegneria Civile, Architettura, Territorio, Ambiente e di Matematica, Università degli Studi di Brescia, Via Branze, 43, 25123 Brescia, Italy
}

\section{A R T I C L E I N F O}

\section{Article history:}

Available online 28 November 2012

\section{Keywords:}

Climate change

Temperate glaciers

Mass balance

Mandrone glacier

Hydrological model

\begin{abstract}
A B S T R A C T
In order to assess the annual mass balance of the Mandrone glacier in the Central Alps an energy-balance model was applied, supported by snowpack, meteorological and glaciological observations, together with satellite measurements of snow covered areas and albedo. The Physically based Distributed Snow Land and Ice Model (PDSLIM), a distributed multi-layer model for temperate glaciers, which was previously tested on both basin and point scales, was applied.

Verification was performed with a network of ablation stakes over two summer periods. Satellite images processed within the Global Land Ice Measurements from Space (GLIMS) project were used to estimate the ice albedo and to verify the position of the simulated transient snowline on specific dates. The energy balance was estimated for the Mandrone and Presena glaciers in the Central Italian Alps. Their modeled balances ( -1439 and $-1503 \mathrm{~mm}$ w.e. year $^{-1}$, respectively), estimated over a 15 year period, are in good agreement with those obtained with the glaciological method for the Caresèr glacier, a WGMS (World Glacier Monitoring Service) reference located in the nearby Ortles-Cevedale group.

Projections according to the regional climate model COSMO-CLM (standing for COnsortium for Smallscale MOdeling model in CLimate Mode) indicate that the Mandrone glacier might not survive the current century and might be halved in size by 2050 .
\end{abstract}

(c) 2012 Elsevier Ltd. All rights reserved.

\section{Introduction}

Glaciers play a fundamental role in many natural ecosystems and are one of the main features of an Alpine landscape. Their value though has to be appraised not only for tourism but also as a microclimate and water resource regulation system and as a significant climate change indicator. Hydropower plants located in Alpine regions are mainly fed by snow- and ice-melt water produced during the ablation season. The hydrological cycle providing the natural inflow to the reservoirs is unavoidably influenced by the presence of glaciers and by their state and dynamics.

Changes in the physical and geomorphological properties of glaciers are considered indicative of climate change [48,63,32]. Reference reports of the Intergovernmental Panel on Climate Change (IPCC) have always listed continental glaciers as a key variable for both the analysis of the global climate system and the detection of local effects of climate change [38-44]. Since the 1980s, at the end of a relatively cold period, these findings have raised interest in monitoring and modelling several glaciers in different parts of the world $[36,37,61,73]$.

\footnotetext{
* Corresponding author. Tel.: +39 0303711294; fax: +39 0303711312.

E-mail address: giovanna.grossi@ing.unibs.it (G. Grossi).
}

Climatic information can be mainly obtained from two types of data from glaciers: mass balance observations and topography change data, such as length and terminus position [43]. A systematic investigation of worldwide glacial mass balance started only in the second half of the last century and their records are generally shorter than instrumental climate records available. For this reason hydrological models were used starting from the 1970s in order to simulate the mass balance of a glacier on the basis of available climatic information $[63,64,74]$.

The retreat of the Alpine glaciers has been observed for almost two centuries: as stated in the last report of the European Environment Agency on the impacts of a changing European climate [24], Alpine glaciers have lost two thirds of their volume since 1850 . This loss has been accelerating since the 1980s and is projected to continue in future decades. Much information has been collected so far and used to keep worldwide glacier inventories up to date, but the effectiveness and efficiency of actions taken to guide strategic climate change measures at the European, national, regional and local levels could be improved with more and more accurate information on specific case studies. In the IPCC Fourth Assessment Report (AR4) [44] the climate change evidence referring to the last decades in Europe is well documented [1], including remarks referring to the 2003 European heat wave which strongly affected all the European glaciers, especially the smallest ones. The 
retreat of Alpine glaciers has been proved with direct measurement of their annual mass balances since the 1960s, as reported for instance by Kaser et al. [47].

For the Alps the climate observed in the last 250 years was studied in detail, for instance, in the HISTALP project [3,12], where the Greater Alpine Region (GAR) was divided into four climatic regions (northwest NW, northeast NE, southwest SW, southeast SE), plus an additional region in the vertical direction above $1500 \mathrm{~m}$ a.s.l. For the whole GAR a mean annual temperature increase of about $2{ }^{\circ} \mathrm{C}$ was detected for the time period between the late 19th century and the beginning of the 21st. For precipitation, no clear pattern was found, in line with Beniston and Jungo [10] or from the results of the STARDEX project [5]. For northern Italy however, an increase in the variability of the snow cover extension and duration was reported for the period 1920-2005 [75].

The word 'vulnerability' is frequently used in climate change impact studies to define the extent to which climate change may damage or harm a system [42]. The extent not only depends on the sensitivity of the system but also on its ability to adapt to new climatic conditions. If the system is a glacier, its response (sensitivity) to climate fluctuations depends on the geomorphologic characteristics, such as topography, aspect, hypsometry and glacier surface conditions including debris cover [49]. The objective of this work is to assess the vulnerability of the largest glacierized area in the Italian Alps, the Mandrone glacier which is the major branch of the Adamello glacier, in terms of mass loss and areal reduction induced by climate change in the 21 st century.

Italian Alpine glaciers, located in the southern Alps, appear to be very sensitive to climate change because of their size and geographical position. Their retreat has been observed since the beginning of the eighties $[6,14,71]$ with a higher intensity for the central and eastern areas than for the western one. The terminus retreat during the 20th century is documented also in Citterio et al. [18], who report an average rate of length retreat in the last century ranging from $-0.5 \mathrm{~m}$ year $^{-1}$ to $-24.7 \mathrm{~m}$ year $^{-1}$ for a subsample of 95 glaciers grouped into four different length categories.

The largest glacier in the southern Alps and in Italy is the Adamello glacier $\left(17.2 \mathrm{~km}^{2}\right.$ in 2003). It is composed of six glacial branches and can be considered representative of other glaciers that are similar from a geomorphologic point of view and falling into the same climatic subregion (SW) of the Alps, among those identified in Auer et al. [3]. In this region a precipitation decrease and a significant temperature increase has been observed in the last decades. In this perspective detailed studies on the energy and mass balances of the Mandrone glacier (13.4 $\mathrm{km}^{2}$ in 2003), the largest branch of the Adamello glacier, were recently performed on the basis of available climatic data between the years 1995 and 2006 and on a physically based energy balance model by Ranzi et al. [69]. The work presented here extends the simulation period analysed in the aforementioned study up to 2009 and takes a step forward in the analysis of the response of the glacier to climatic fluctuations, by defining future climate change scenarios and simulating the energy and mass balances projected to the 21st century, estimating the glacier's extent evolution as a response to climate forcing.

The geographical area and the considered hydrographic units are presented in the next section, which is followed, in Section 3, by the description of the selected methods (including their validation) and scenarios. Results and comparison with the mass balances of the nearby Presena and Caresèr glaciers are discussed in Section 4. This analysis is intended to support climate change impact assessment for natural systems in similar climatic and geomorphologic conditions, and for evaluating the potential natural or artificial adaptation strategies. Climate change adaptation is in fact one of the key points of the sustainable development strategies of the regions hosting the Mandrone glacier, as well as of the environmental directives at the European and national levels $[26,45]$.

\section{Study site and data}

\subsection{Adamello, Mandrone, Presena and Caresèr glaciers}

The Adamello glacier (Fig. 1) is located on the AdamelloPresanella mountain group [21] belonging to the Rhaetian Alps (central southern Alps). Measuring $17.24 \mathrm{~km}^{2}$ in 2003 [69], it is the largest glacierized area of the Italian Alps. It lies on a plateau at an average altitude of $3000 \mathrm{~m}$ a.s.l. with radial patches and can be considered as a Scandinavian-type glacier [58]. It has six hydrographical units: the Mandrone glacier is the largest in size, covering an area of $13.38 \mathrm{~km}^{2}$.

From an administrative point of view $90 \%$ of the Adamello glacier surface belongs to Lombardy, the remaining part to TrentinoAlto Adige/Südtirol (Fig. 1). Ice-melt feeds both the Oglio and the Sarca river, but the Mandrone glacier is part of the Sarca river basin only [7].

The computation spatial domain of the hydrological model was defined according to the boundaries of the Mandrone glacier (coded as I-4L01011-15 in the World Glacier Inventory), forming an ice tongue that developed in the northeast direction. Its altitude ranges between 2586 and $3406 \mathrm{~m}$ a.s.l. The equilibrium line altitude (ELA) was estimated for the 1990s by Baroni and Carton [7] at $2994+18 /-23 \mathrm{~m}$ and for the whole Adamello glacier ELA was estimated equal to $3014+17 /-18 \mathrm{~m}$.

Presena is a small north-facing glacier belonging to the Adamello-Presanella group. Its altitude ranges between 2700 and $3000 \mathrm{~m}$ a.s.l. Recent attempts were undertaken to protect this glacier by covering it with reflecting covers and by artificial snow generation. These measures were effective in reducing the ice mass loss of the glacier.

Focusing attention on the area of the Central Italian Alps around the Adamello-Presanella mountain group, the Caresèr glacier is a fundamental reference. For this glacier, which faces southward and had an extension of about $2.8 \mathrm{~km}^{2}$ in 2011, the mass balance has been measured with the glaciological method systematically since 1967 [31,79] and it is still performed today [17], thus providing the longest time series of mass balance for the Italian Alps and a precious reference for mass balance studies in the Central Alps. Shorter time series are available for other glaciers close to the Adamello group (see for example $[23,46]$ ).

After the glacial advance in the Little Ice Age, for the majority of Alpine glaciers a retreat began and is still going on today in most cases. For the Mandrone glacier a retreat of about $2 \mathrm{~km}$ and an increase of $880 \mathrm{~m}$ in the elevation of the front were observed in the period 1820-2002. Recently Maragno et al. [55] compiled changes in the areal extent of the Adamello group glaciers, resulting in a $19 \%$ surface reduction from 1983 to 2003, which was faster than the $22 \%$ average reduction in the Alpine glacier cover estimated over the 1970-2000 period, as reported in [78]. For the Mandrone glacier in 1997 the terminus was located at an altitude of 2520 m a.s.l. [56,57,69]. In the 1960s, seismic measurements along four different profiles determined a maximum thickness of $260 \mathrm{~m}$ [15]. The maximal ice thickness in the Pian di Neve, close to Passo Adamè, was assessed to be $240 \mathrm{~m}$ and total ice volume was estimated to be $870 \times 10^{6} \mathrm{~m}^{3}$, through radio-echo sounding conducted between 1997 and 1998 [28].

For the Caresèr glacier, mass balance series since 1967 have been presented by Carturan and Seppi [17], completing the time series of mass balances estimated with the glaciological method by Zanon [79] and Giada and Zanon [29]. During the period from 2002 to 2005, an average negative mass balance of $2008 \mathrm{~mm} \mathrm{year}^{-1}$ was 

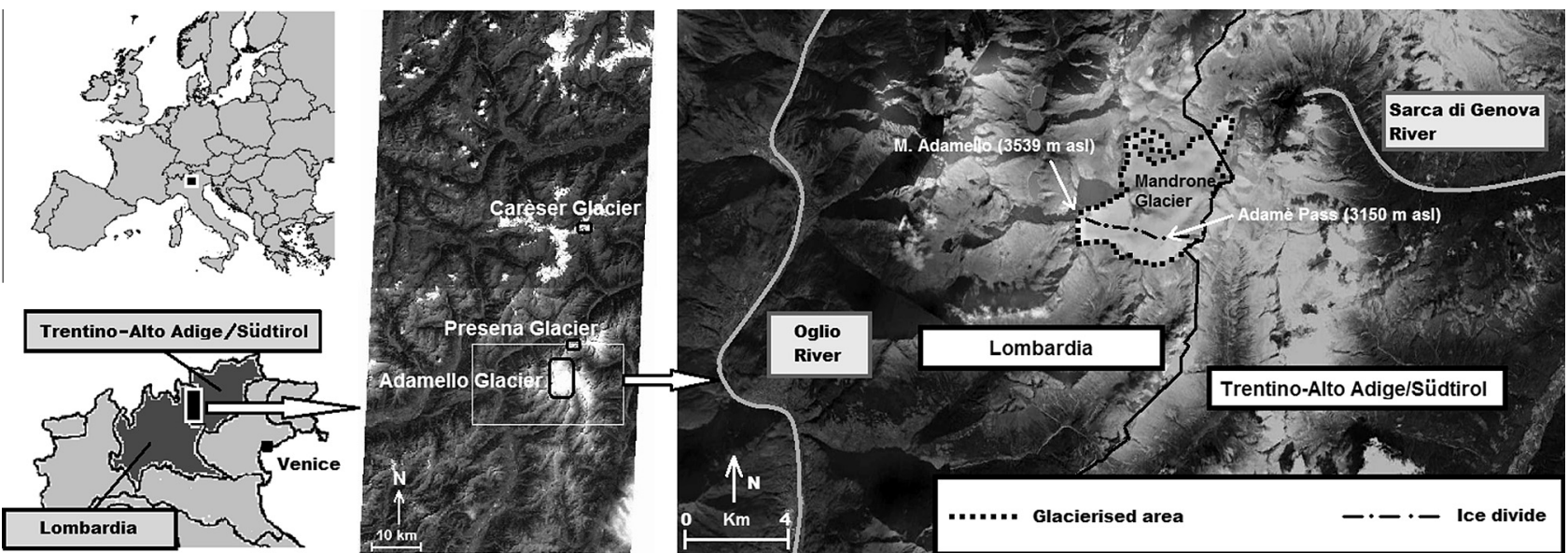

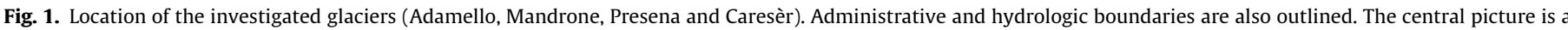
quick-look at the ASTER satellite image of 25.08.2007.

recorded, while the corresponding value for the period from 1981 to 2001 was $1195 \mathrm{~mm}$ year $^{-1}$. The Authors observe that there is a strong correlation between ablation season temperatures and mass balance series, while the relationship with winter accumulation is not so clear. Positive feedback has also contributed to the fast glacial retreat, so that in a few decades it is expected to disappear, a fate that might be common to many glaciers in the Alps [80].

\subsection{Meteorological, snow, ablation and satellite measurements for the Mandrone glacier}

For the time period 1995-2009, hourly meteorological observations were recorded at 17 weather stations located in the study area and in its surroundings, as shown in [69]; 15 sets of point observations of snow depth and density were also collected every 15 days in April and on a monthly basis from January to the end of
May. These data were used to assess the snow water equivalent at the end of the accumulation season. Most of the monitoring sites are situated at altitudes between 900 and $2000 \mathrm{~m}$ a.s.l., some are located above $2000 \mathrm{~m}$ a.s.l.

Priority was given to physical and meteorological data measured at higher altitudes. The reference meteorological stations were Passo Adamè (3150 m a.s.l.) for the years 1995 and 1996, Cima Presena (3015 m a.s.l.) between 1997 and 2000 and for years 2008 and 2009, and Passo della Lobbia Alta (3020 m a.s.l.) from 2001 to 2006. The last reference station was placed between the Adamello glacier (just a few tens of metres apart) and the adjacent Lobbia glacier and recorded air temperature and humidity, net radiation (both shortwave and longwave) and incident and reflected global radiation. In the summer 2007 a station was installed on the Mandrone glacier at $2780 \mathrm{~m}$ a.s.l. (Fig. 2). The meteorological data of the surrounding stations (Cima Presena, Capanna Presena,

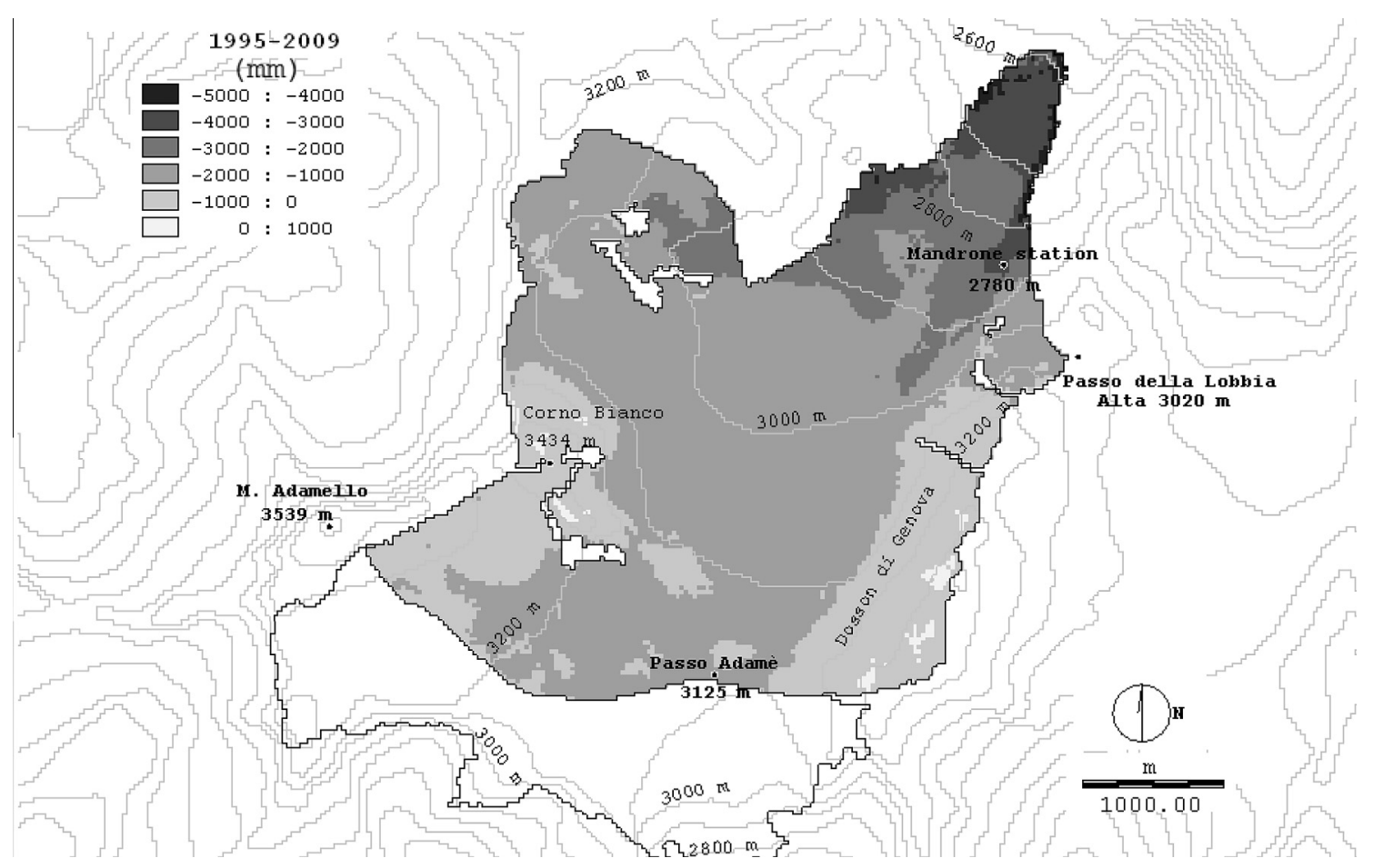

Fig. 2. Mean annual mass balance (mm w.e.) for the Mandrone glacier for the control period 1995-2009. 
Pantano d'Avio, Passo del Tonale) were used to fit linear regression curves to fill data gaps of time series recorded by the glacier stations (Passo Adamè, Passo della Lobbia Alta, Mandrone) which were used in this study.

Discharge observations are available for the Sarca river at Ponte Maria, located at $1100 \mathrm{~m}$ a.s.l. The drainage basin, including the Mandrone glacier, has an area of $77.52 \mathrm{~km}^{2}$ and a glacierization of $25 \%$. Ablation stake measurements were also performed during two melt seasons and were used for model validation as described in the next section.

An ice albedo map was estimated by processing radiation maps derived from a $15 \mathrm{~m}$ resolution ASTER (Advanced Spaceborne Thermal Emission and Reflection Radiometer, installed on TERRA satellite) image acquired on 23 August 2003 [69] and made available within the GLIMS project (www.glims.org).

\section{Methods}

The hydrologic vulnerability of the Mandrone glacier was investigated by projecting the 15-year meteorological observations for the 1995-2009 'control period' on the glacierized area into two future time periods of 20 years (2040-2060 and 2079-2099) according to two different scenarios, B1 and A1B, as defined by the IPCC special report on emission scenarios [59]. The meteorological input to the Physically based Distributed Snow Land and Ice Model (PDSLIM), that is an hourly time series of precipitation, wind velocity, global radiation, air temperature, pressure and humidity, was derived from the output of a regional climate model called COSMO-CLM (standing for COnsortium for Small-scale MOdeling model in Climate Mode (developed by Deutscher Wetterdienst).

Statistical analysis of CLM output provided the information needed to modify the meteorological forcing for PDSLIM. The time series of meteorological data measured in the 15-year control period were transformed in order to build the meteorological forcing to PDSLIM in a modified climate scenario, as explained in Section 3.2. Therefore the modified climate forcing is not the result of pure modeling simulations, but the outcome of transformations of real recorded values. This is an advantage of the technique used with respect to using time series provided directly by regional climate models, which could be inaccurate in reproducing local climate. Indeed, beyond the average variation of each meteorological variable, several features characterizing local meteorological conditions are maintained: extreme cold or hot periods, very intense rainfall or drought, as well as intermediate states, assuming that such patterns will be repeated, on average, in the future. The use of two scenarios, an optimistic one, B1, and a moderately pessimistic one, A1B, and the selection of two time windows led to the definition of four different possible evolution scenarios of the glacier: (i) scenario B1 at 2050, (ii) scenario B1 at 2090, (iii) scenario A1B at 2050 and (iv) scenario A1B at 2090. The response of the glacier to the projected change in climate is finally evaluated and compared to actual conditions on the basis of the mass balance, both distributed and averaged over the glacierized area, resulting from the application of the hydrological energy-balance model. Mass balance evaluation was also used to predict the change in size of the glacier with a simplified ice flow model as described in detail in Section 3.4.

\subsection{The regional climate model CLM}

Detailed studies on the future climatic evolution in the Alpine area until the end of the 21st century were conducted for instance by the European Environment Agency (EEA) [25] and within the ClimChAlp project [19], based on simulations by regional climate models (RCMs). The EEA report projects a further increase in the upward temperature trend in the GAR. Most affected areas of the GAR are expected to be in the South-West sub-region (SW) as well as in areas located above $1500 \mathrm{~m}$ a.s.l.: the Adamello group belongs to both. Regional climate models were adopted, among others, by Machguth et al. [53] for the calculation of glacier mass balance distribution in the Swiss Alps and by López-Moreno et al. [51] to assess future snow cover in the Pyrenees.

The ClimChAlp project focused on the systematic validation of the regional climate models RegCM, REMO, HIRHAM, CLM, MM5 and ALADIN for the Alpine Space. The control run outputs of these models were compared with a number of available climatology data based on observations. The comparison outlined how all the RCMs have particular difficulties reproducing the seasonal average precipitation amounts, which they tend to significantly overestimate in winter, while in summer simulated precipitations are a little lower than the observed data. The precipitation biases show seasonal and regional patterns that are typical for the individual model. The structure of the spatial and seasonal bias of each RCM clearly indicates orographic and seasonal effects; however, the climate change signal of each model is more significant [19].

CLM data were made available for this study by the World Data Center for Climate (WDCC). The main features of CLM and the runs available for this study are shown in Table 1 . The rainfall regime observed on average on the Oglio basin $\left(1840 \mathrm{~km}^{2}\right)$ was compared with CLM simulation (coded as C20 in the WDCC database) on a computational grid covering the basin. The mean annual observed precipitation of $1165 \mathrm{~mm}$ is overestimated by $9 \%$. The simulated monthly precipitation maxima in October and May match the observations quite well, as shown in Fig. 3. Also the precipitation decrease in summer and November is well reproduced. Discrepancies between the model and the observations are comparable with those reported by Barontini et al. [9] and Groppelli et al. [30], who analysed the signals of three Global Climate Models in an area including the Adamello glacier. Also the temperature regime is fairly in agreement with observations, at least in the summer period, as will be discussed in Section 4. For the above reasons CLM was adopted for our investigations.

The CLM A1B scenario projects a temperature increase for the entire Alpine region of $+3.9^{\circ} \mathrm{C}$ by the end of the $21 \mathrm{st}$ century, while the increase over the European territory equals $+3.3^{\circ} \mathrm{C}$. The warming is expected to be stronger at higher altitudes: $+4.2{ }^{\circ} \mathrm{C}$ above $1500 \mathrm{~m}$. This increase would be the result of two distinct trends: the first less marked one (about $+1.4^{\circ} \mathrm{C}$ ) from present day up to the middle of the century, followed by a much stronger one, from 2050 up to 2100 (at least $+2.5^{\circ} \mathrm{C}$ ). According to the CLM B1 scenario, the temperature increase by 2100 would be less pronounced: $+2.6{ }^{\circ} \mathrm{C}$ in two steps, $+1.0^{\circ} \mathrm{C}$ for the first half and $+1.6{ }^{\circ} \mathrm{C}$ for the second half of the century.

Table 1

Regional climate model characteristics.

CLM climate simulation data

Data compilation Model and Data Group, MPI for Meteorology, Hamburg

Model CLM 2.4.11 (Climate mode of the Local Model of the DWD)

- Dynamic model

- Drive: ECHAM5/MPIOM

- Non-hydrostatic

Model region Europe

Simulation

From 1960 to 2100 (control run begins January 1, 1955 at period 00:00 UTC. The model results are available by January 1 , 1960 at 00:00 UTC. The first five years of the simulation are the spin-up phase)

IPCC emission A1B, B1 (from 2001)

scenarios

Resolution

$0.165^{\circ}-0.200^{\circ}$ (approx. $15 \times 23 \mathrm{~km}^{2}$ for the Adamello area) 


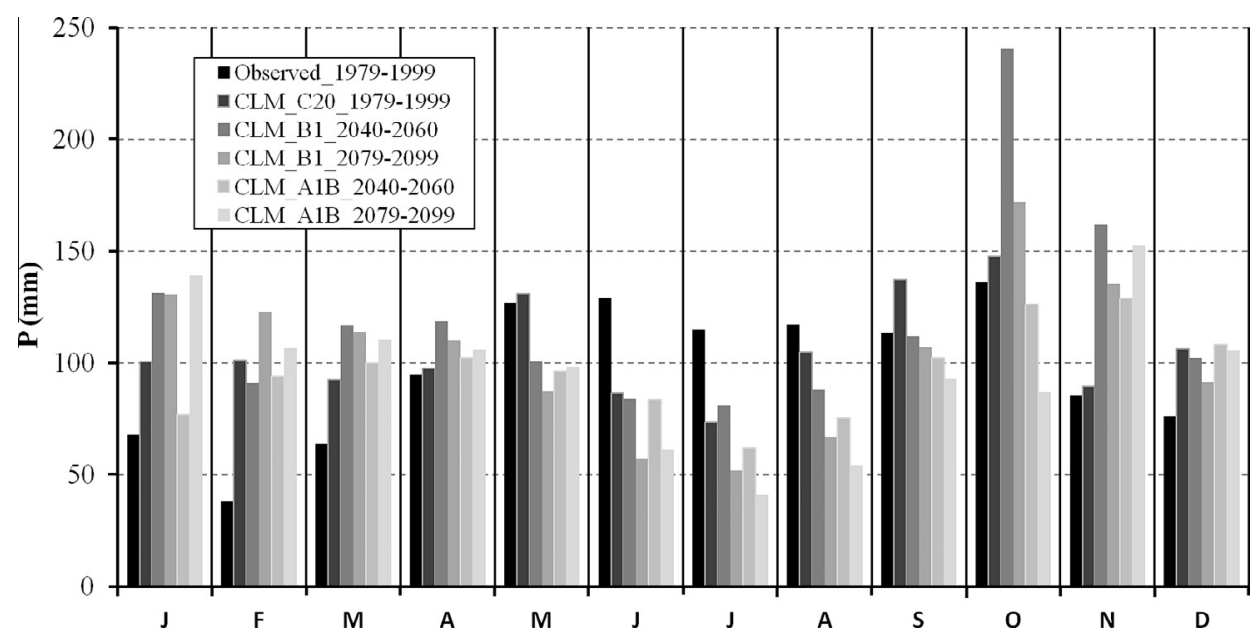

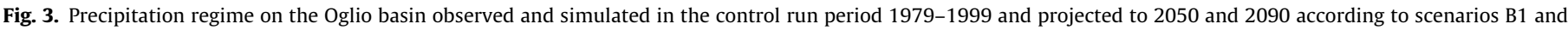
$\mathrm{A} 1 \mathrm{~B}$, as projected by CLM.

Seasonality would also characterize the temperature change. The strongest increase is expected in summer, with an average of $+4.8^{\circ} \mathrm{C}$ (A1B), but peaks up to $+6{ }^{\circ} \mathrm{C}$ are foreseen for the highest mountain areas. A lower increase is expected in spring (on average $+2.7^{\circ} \mathrm{C}$, for $\mathrm{A} 1 \mathrm{~B}$ ).

On the other hand, trends in precipitation are still burdened with considerable uncertainty. Differences between results of climate models driven by the same emission scenario are often larger than those occurring by using different emission scenarios in a single climate model. The potential impact of the uncertainty in climate projections on the Mandrone glacier mass balance will be briefly discussed in Section 4.1. However, a consistent feature of modeling results for the Alpine region is the projected increase in winter precipitation and decrease in summer precipitation [19].

\subsection{Transformation of data series}

The climate model daily output runs of scenarios B1 and A1B were used to project the 1995-2009 observed meteorological time series to the 21st century, in order to build a climate change meteorological input for the hydrological model simulations. Eight adjacent CLM grid cells around the location of the Adamello massif were examined, including the one, named G-cell, containing the Mandrone glacier and characterized by an average altitude of $2168 \mathrm{~m}$ a.s.l.

The CLM_1979-1999 meteorological output (named control scenario, since it refers to past years) was analysed and compared to projected meteorological time series provided by CLM for the time period 2040-2060 and 2079-2099 (referred to in the following by the intermediate year: 2050 and 2090), for both B1 and A1B scenarios. The time series of meteorological observations recorded by the stations located on and near the Mandrone glacier were also transformed to consider climate change scenarios. For precipitation, solar radiation and air humidity a multiplicative adaptation of observed data to future scenarios was applied ( $k$-method). Observations in the control period are transformed to the future scenarios by multiplying them by a monthly factor $k$ representing the ratio between RCM-projected values and the respective values in the control period run. Only for the air temperature, the monthly differences $(\Delta)$ were applied (see also [51] for the so-called $\Delta$ method). Multiplicative $k_{w}$ factors for the entire winter semester were used to assess the winter mass balance, which is assessed on the basis of snow w.e. accumulation on the 1st of April of each year, assuming that at the glacier altitude in winter only solid precipitation occurs, a reasonable hypothesis supported by the winter temperatures projected at the glacier's mean altitude and a temperature-based snow-rain partitioning model [68]. No significant change was detected as regards surface pressure and wind speed at $2 \mathrm{~m}$ above the surface.

The time series of average daily temperature for each of the eight selected cells were analysed. Through a linear regression of daily temperature vs. the cell height, daily temperature at $3020 \mathrm{~m}$ a.s.l. (Passo della Lobbia Alta monitoring station) was computed. The temperature increase by 2050 is meaningful compared to the 1979-1999 period, more pronounced for the A1B scenario, and still strong in both scenarios at the end of 21 st century.

Changes in the other input parameters were evaluated only for the G-cell and compared to the average value over the spatial domain defined by the eight selected cells. Rainfall, as previously reported for the entire GAR, is also expected to decrease in the G-cell in summer and to increase in winter, as shown in Table 2. Projections of relative humidity show a decrease with the exception of November (when a substantial increase in precipitation can also be noticed). Global radiation is expected to increase slightly in summer months, and decrease in other seasons, especially in spring, probably as a consequence of a cloud cover increase.

\subsection{Energy and mass balance of snow and ice: the physically based hydrological model}

The annual specific mass balance of the Mandrone glacier was estimated for each year, between 1995 and 2006 in a previous work [69] and between 2007 and 2009 in this study, as the sum of the winter balance and of the summer balance, each lasting six months. The winter balance was estimated by interpolating snow water equivalent measurements at the beginning of April with geostatistical methods. To consider the effect of avalanches and gravitational snow transport [11] a 5\% increase of the interpolated snow water equivalent was adopted, as estimated on the basis of the area of the steepest mountain slopes surrounding the glacier. The influence of snow transport by wind $[22,50,65]$ was neglected, instead. Summer specific mass balance from the 1 st of April to the 30th of September of each year, was computed by simulation of the mass and energy balance with the distributed hydrological model PDSLIM (Fig. 4), adopting a modelling framework similar to other studies of this type [60,62].

The results of previous applications to the Mandrone glacier were tested both at the point and at the basin scale, using ablation 
Table 2

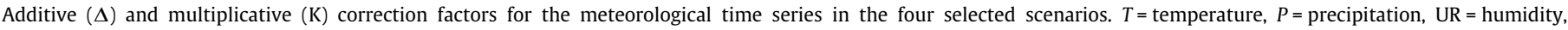
$R g=$ radiation.

\begin{tabular}{|c|c|c|c|c|c|c|c|c|c|}
\hline & \multirow[t]{2}{*}{ Parameter } & \multirow[t]{2}{*}{ Correction factor } & \multicolumn{6}{|c|}{ Summer } & \multirow{2}{*}{$\begin{array}{l}\text { Winter } \\
\text { ONDJFM }\end{array}$} \\
\hline & & & A & M & $\mathrm{J}$ & $\mathrm{J}$ & A & $S$ & \\
\hline \multirow{4}{*}{ CLM B1 2050} & $T\left({ }^{\circ} \mathrm{C}\right)$ & $\Delta\left({ }^{\circ} \mathrm{C}\right)$ & 0.15 & 0.84 & 1.67 & 0.44 & 0.93 & 1.38 & - \\
\hline & $P\left(\mathrm{~kg} \mathrm{~m}^{-2}\right)$ & $\mathrm{K}(-)$ & 1.24 & 0.75 & 1.00 & 1.17 & 0.81 & 0.76 & 1.35 \\
\hline & UR (\%) & $\mathrm{K}(-)$ & 1.00 & 1.01 & 0.99 & 1.01 & 1.02 & 0.98 & - \\
\hline & $R_{\mathrm{g}}\left(\mathrm{W} \mathrm{m}^{-2}\right)$ & $\mathrm{K}(-)$ & 0.93 & 0.97 & 0.99 & 0.97 & 0.99 & 1.01 & - \\
\hline \multirow[t]{4}{*}{ CLM B1 2050} & $T\left({ }^{\circ} \mathrm{C}\right)$ & $\Delta\left({ }^{\circ} \mathrm{C}\right)$ & 1.80 & 4.08 & 4.54 & 3.00 & 3.63 & 3.19 & - \\
\hline & $P\left(\mathrm{~kg} \mathrm{~m}^{-2}\right)$ & $\mathrm{K}(-)$ & 1.12 & 0.67 & 0.71 & 0.68 & 0.70 & 0.70 & 1.17 \\
\hline & UR (\%) & $\mathrm{K}(-)$ & 0.97 & 0.92 & 0.90 & 0.92 & 0.97 & 0.91 & - \\
\hline & $R_{\mathrm{g}}\left(\mathrm{W} \mathrm{m}^{-2}\right)$ & $\mathrm{K}(-)$ & 0.92 & 0.99 & 1.04 & 1.02 & 1.04 & 1.06 & - \\
\hline \multirow[t]{4}{*}{ CLM A1B 2050} & $T\left({ }^{\circ} \mathrm{C}\right)$ & $\Delta\left({ }^{\circ} \mathrm{C}\right)$ & 1.16 & 2.38 & 2.89 & 1.24 & 2.15 & 1.47 & - \\
\hline & $P\left(\mathrm{~kg} \mathrm{~m}^{-2}\right)$ & $\mathrm{K}(-)$ & 1.02 & 0.71 & 0.93 & 0.85 & 0.70 & 0.67 & 0.96 \\
\hline & UR (\%) & $\mathrm{K}(-)$ & 0.96 & 0.93 & 0.95 & 1.00 & 0.98 & 0.99 & - \\
\hline & $R_{\mathrm{g}}\left(\mathrm{W} \mathrm{m}^{-2}\right)$ & $\mathrm{K}(-)$ & 0.93 & 0.99 & 1.02 & 0.98 & 1.03 & 1.01 & - \\
\hline \multirow[t]{4}{*}{ CLM A1B 2090} & $T\left({ }^{\circ} \mathrm{C}\right)$ & $\Delta\left({ }^{\circ} \mathrm{C}\right)$ & 2.59 & 6.05 & 6.45 & 5.47 & 5.32 & 4.74 & - \\
\hline & $P\left(\mathrm{~kg} \mathrm{~m}^{-2}\right)$ & $\mathrm{K}(-)$ & 1.17 & 0.75 & 0.71 & 0.64 & 0.52 & 0.65 & 1.08 \\
\hline & UR (\%) & $\mathrm{K}(-)$ & 0.94 & 0.89 & 0.87 & 0.92 & 0.91 & 0.91 & - \\
\hline & $R_{\mathrm{g}}\left(\mathrm{W} \mathrm{m}^{-2}\right)$ & $\mathrm{K}(-)$ & 0.86 & 0.97 & 1.05 & 1.01 & 1.06 & 1.06 & - \\
\hline
\end{tabular}

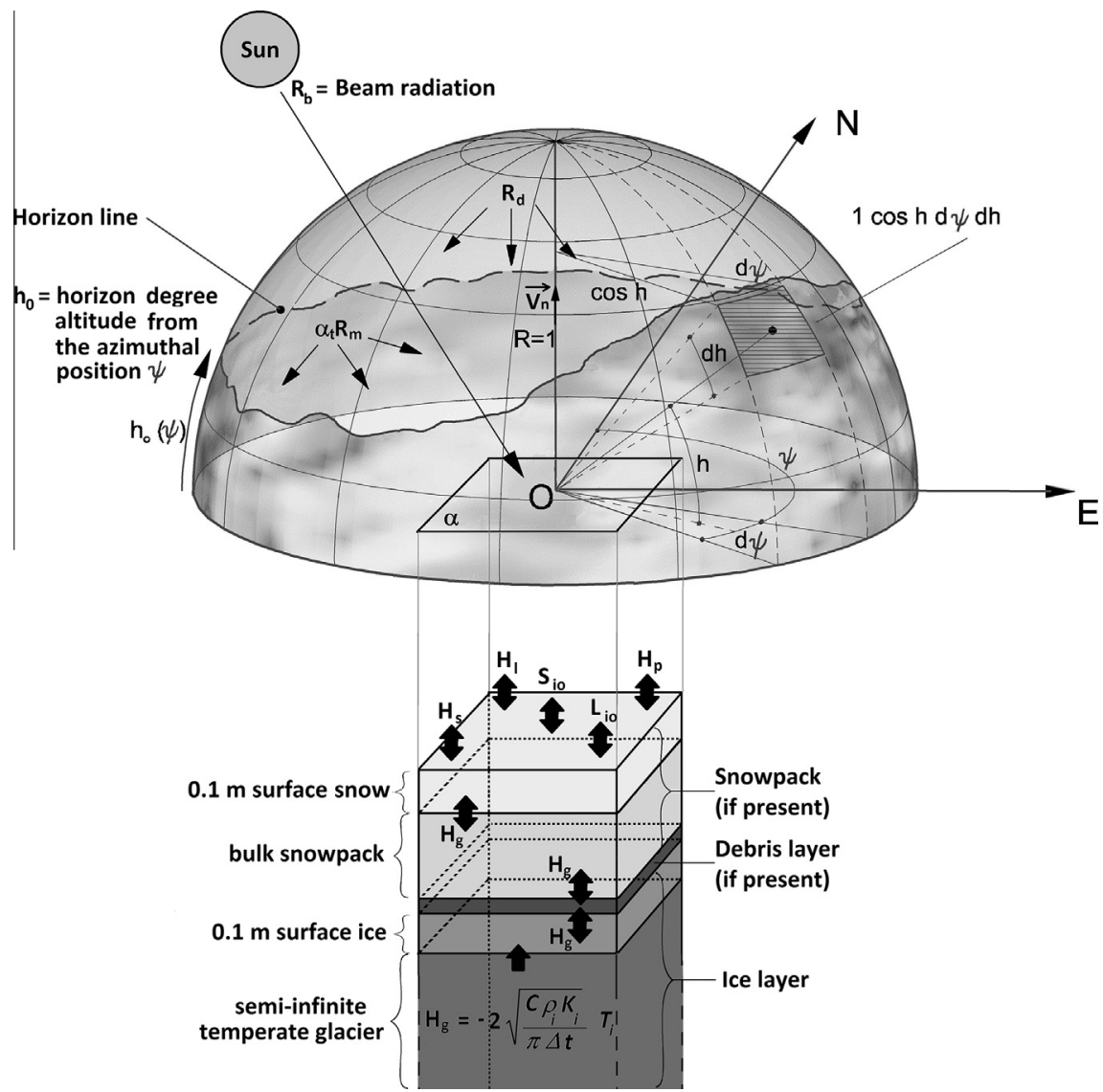

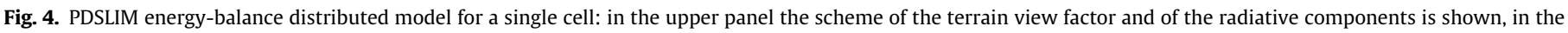
lower panel the multi-layer snow-debris-ice column is represented together with the symbols of the heat fluxes.

stake measurements, runoff data and snow cover data for verification.

For a unit area and finite depth layer of ice or snow superimposed over ice, the melt rate can be computed from the energy balance equation:

$H_{m}+H_{c}=S_{i o}+L_{i o}+H_{l}+H_{s}+H_{p}+H_{g}$

where each term stands for energy in unit time and unit area $\left(\mathrm{W} / \mathrm{m}^{2}\right)$, respectively:
$H_{m}$ : energy flux available for melt,

$H_{c}$ : rate of gain of internal energy of the ice or snow layer,

$S_{i o}$ : net incoming shortwave radiation,

$L_{i o}$ : net incoming longwave radiation,

$H_{l}$ : latent heat,

$H_{s}$ : sensible heat,

$H_{p}$ : advective heat from precipitation,

$H_{g}$ : conductive heat at the bottom surface of the ice or snow layer. 
For an ice or snow layer with finite depth $\Delta z$, specific heat capacity $C$, density $\rho$ and mean temperature $T$, thermal energy changes at a rate:

$$
H_{c}=C \rho \Delta z d T / d t
$$

The specific heat capacity of ice is set to $C=C_{i}=2093.4 \mathrm{~J} \mathrm{~kg}^{-1}{ }^{\circ} \mathrm{C}^{-1}$ and its density is assumed $\rho=\rho_{i}=830 \mathrm{~kg} \mathrm{~m}^{-3}$, a literature value for firn [64]. This value can also be adopted for ice at the surface, where ice porosity is high. For snow, instead, density $\rho=\rho_{\text {s }}$ changes over time according to the snowpack simulation model already described in $[66,13]$. Details of the computation of $S_{i o}$ and $L_{i o}$, using measured shortwave radiation are reported in [66,67].

It is briefly recalled here that shading is computed with a suntracking algorithm and a cloudiness index is estimated by comparing measured global shortwave radiation on a horizontal surface, $R_{m}$, with clear-sky radiation. With reference to Fig. 4 for the meaning of each symbol, direct radiation on each computational cell, measuring $30 \times 30 \mathrm{~m}^{2}$ and centred in $\mathrm{O}$, is obtained by projecting with the scalar product estimated beam radiation $\boldsymbol{R}_{\boldsymbol{b}}$ on the local vector normal to the surface, $\boldsymbol{V}_{\boldsymbol{n}}$. Diffused radiation from the sky, $R_{d}$, is weighed by the sky view factor, $V_{s}=1-V_{t}$, being $V_{t}$ the terrain view factor defined as a function of the horizon angle $h_{0}(\psi)$ in each azimuthal direction $\psi$ :

$V_{t}=\frac{1}{\pi} \int_{0}^{2 \pi h} \int_{0}^{h_{0}(\psi)} \cos (h) \sin (h) d h d \psi=\frac{1}{\pi} \int_{0}^{2 \pi} \frac{1}{2} \sin ^{2}[h(\psi)] d \psi$

Terrain surrounding each point reflects incoming measured radiation with a spatially-averaged albedo $\alpha_{t}$

$S_{i n}=-\boldsymbol{R}_{\boldsymbol{b}} \cdot \boldsymbol{V}_{\boldsymbol{n}}+V_{s} R_{d}+V_{t} \alpha_{t} R_{m}$

The net incoming shortwave radiation results as $S_{i o}=S_{i n}(1-\alpha)$, being $\alpha$ local albedo. Ice-albedo is derived from a map estimated from the radiation detected from the sensor ASTER satellite image dated 23 August 2003, when the glacier was almost snow-free. Future ice albedo is assumed to remain as in actual conditions. For snow-covered areas albedo is computed as a function of temperature-dependent snow-ageing and diffused radiation [66] and therefore it changes according to climate change scenarios.
Net longwave radiation, $L_{i o}$, is computed assuming snow and ice as black bodies and the Satterlund model for atmospheric emissivity [72].

Convective fluxes of latent heat, $H_{l}$, and sensible heat, $H_{s}$, are computed according to the mixing length theory [69].

In PDSLIM the ice is modelled as a $0.1 \mathrm{~m}$ thick surface layer with temperature $T_{i}$ superimposed to a semi-infinite ice layer at constant $0^{\circ} \mathrm{C}$ temperature, a reasonable assumption for a temperate glacier in the melt season. The surface layer can be covered by a debris layer, as occurred for instance in an earlier application of the model to simulate melt for the Belvedere glacier, in the Western Italian Alps [70]. If this layer does not exist as for the Mandrone glacier, ice can be covered by a snowpack, modelled as a surface layer with $0.1 \mathrm{~m}$ thickness, superimposed to the bulk snowpack. The snowpack model, described in [66,13], simulates snow temperature, density, depth and liquid water content. Conductive heat fluxes in snow and ice, $H_{g}$, are computed with the Fourier law and melt infiltration assuming Colbeck's celerity $[20,66]$. The model does not account for snow transformation into firn and ice.

The snowpack model was validated with in situ snowpack temperature and depth measurements and brightness temperature measurements by microwave radiometers at C- $(6.8 \mathrm{GHz}), \mathrm{Ku}-$ $(19 \mathrm{GHz})$, and Ka-band $(37 \mathrm{GHz})$ operating in vertical and horizontal polarizations during the MASMEX 2002 and 2003 experiment $[13,52]$. As a further verification criterion the dynamics of the snowpack extent simulated during the 2003 ablation season was compared with satellite-derived snow cover in the AdamelloPresanella group, as described in [69].

Concerning the validation of the ice melt model in PDSLIM, a glaciological survey in the 2007 ablation season was carried out: 29 ablatometric stakes, characterized by different altitudes and exposure to solar radiation, were placed in different points on the glacier surface, as shown in Fig. 5, at altitudes ranging from 2640 to $3117 \mathrm{~m}$ a.s.l. The stakes used were PVC graduated bars having a $2 \mathrm{~cm}$ diameter and a $3 \mathrm{~m}$ length. Considering the measurements in July and August, the mean bias of the simulated vs. the measured ablation period was $-1.6 \%$ : the mean observed value was $1148 \mathrm{~mm}$ w.e., the mean simulated value was $1130 \mathrm{~mm}$ w.e., with a RMSE of $319 \mathrm{~mm}$.
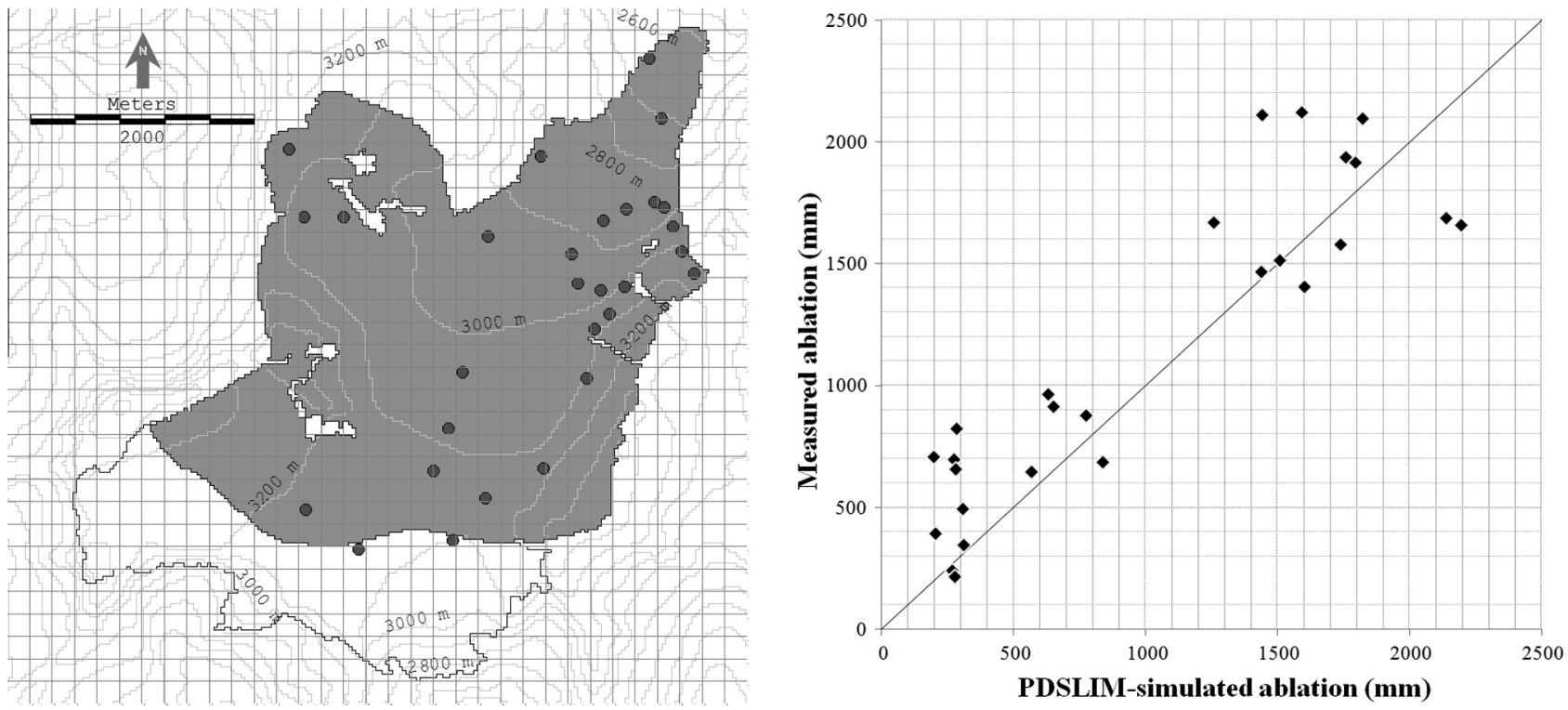

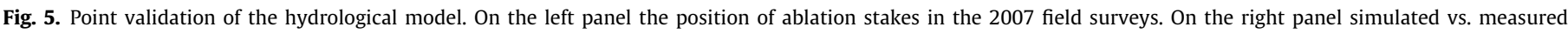
ablation at ablation stakes. 
A similar intercomparison between simulated and measured ablation was conducted on a network of 14 ablation stakes installed in 2008 on the Mandrone glacier at an altitude ranging from 2780 to $3117 \mathrm{~m}$ a.s.l. The mean bias of simulated vs. measured ablation in the July to August monitoring period was $-2 \%$ and the RMSE was $159 \mathrm{~mm}$ compared to a mean measured value of $848 \mathrm{~mm}$.

\subsection{Ice flow modeling}

In order to account for glacier evolution in a transient climate, a simplified model of ice dynamics was connected off-line to PDSLIM to evaluate the flow of the Mandrone glacier, assumed as a parallel-sided ice slab with depth $D$. In the model the continuity equation and the balance of momentum and internal energy are enforced, as described in detail in [54]. The constitutive relationships adopted for the rate of internal energy, heat flux and stress are the heat equation for a viscous fluid, the Fourier law, and a special case of the Reiner-Rivlin constitutive law. Stress is linked to strain rate via Glen's flow law [34,64].

According to Weertman's theory of sliding [76,77], the following basal boundary condition is assumed:

$u=\zeta \cdot \tau^{m}$

where $u$ is the sliding velocity, $\zeta$ is a function of the bed roughness, $\tau$ is the shear stress at the base and $m \approx 2$, a value adopted in the following.

In the study of the Mandrone glacier a dimensionless form of the problem was introduced, by normalizing the depth $\bar{y}=y / D$ and the velocity $\bar{u}=u \cdot \Theta / D$, where $\Theta$ is a time scale; moreover stress, velocity and temperature fields were considered $x$-independent (the $x$-axis is parallel to the average bedrock slope angle $\gamma$ ).

Considering the $y$-axis pointing upward, the vertical velocity profile $\bar{u}(\bar{y})$ is described by:

$\bar{u}(\bar{y})=C \cdot \sin ^{m} \gamma+2 \int_{0}^{\bar{y}} \exp (A \vartheta)\left(\sin ^{n} \gamma(1-\varepsilon)^{n}\right) d \varepsilon$

where $C$ is the basal friction number according to the Weertman's theory, assumed here to be 10.9 [34], $n=1$ is the value of the exponent adopted in Glen's flow law, and $A$ is the Arrhenius number, equal to 0 for temperate glaciers according to the same law.

\section{Results and discussion}

\subsection{Effects of climate change scenarios on the Mandrone glacier mass balance}

By transforming the meteorological time series of the period between 1995 and 2009, the Mandrone glacier mass balance projected to 2050 and 2090 was computed according to two different scenarios (B1 and A1B) of the emissions dynamics. Calculated winter, summer and annual mass balance are listed in Table 3. The average distribution of the specific mass balance for the control run (15 years) is depicted in Fig. 2. Average mass loss was $-1439 \mathrm{~mm}$ w.e. year $^{-1}$. The effect of the ice flow in redistributing the ice mass from the upper part of the glacier to the lower part can be obtained by solving the 2-D mass conservation equation on the area of interest. For instance, the integration of Eq. (6) along the median altitude line at $3070 \mathrm{~m}$ a.s.l., which divides the glaciers into two equal areas, provides a mass flux through the transverse surface. This mass flux causes an annual displacement of $670 \mathrm{~mm}$ w.e. from the upper half area of the glacier to the lower part. This amount has to be subtracted from the upper area mass balance of $-938 \mathrm{~mm}$ w.e. year $^{-1}$ derived from the PDSLIM modelling and added instead to the $-1968 \mathrm{~mm}$ w.e. year $^{-1}$ balance of the lower part.

The estimated mass flux is highly uncertain, since parameters setting for the simplified flux model is a difficult task. For instance a $\pm 30 \%$ change in the value of the $C$ basal friction number parameter is reflected in a $\pm 210 \mathrm{~mm}$ change in the ice flux between the two portions of the glacier's area.

Considering future climate scenarios, the average mass loss is expected to increase by the year 2050 up to about $-2000 \mathrm{~mm}$ w.e. in the moderate B1 scenario and to $-3000 \mathrm{~mm}$ w.e. in the pessimistic A1B scenario. The first feature deserving attention is the inbalance between winter gross gain in water equivalent and the summer melt loss in each future scenario and in the observed years (Fig. 6). The annual deficit will increase in future scenarios with respect to control run outputs. According to CLM+PDSLIM projections, summer melt will increase in all scenarios, with dramatic effects especially in the last two decades of the current century. The winter precipitation predicted by CLM is assumed to be entirely snow as the temperature projected at the average glacier's altitude during precipitation events remains below $0{ }^{\circ} \mathrm{C}$ for most of the six month period in each of the considered scenarios. Only for the A1B_2090 scenario rain precipitation at $3000 \mathrm{~m}$ a.s.l. would exceed $1 \%$ of winter semester precipitation. Even an increase of $35 \%$ of winter snow precipitation, with a weak summer temperature increase $\left(+0.9{ }^{\circ} \mathrm{C}\right)$ for the B1_2050 scenario, would not compensate the increased ice and snow melt between April and September, as Fig. 6 shows.

The magnitude of the change in mass balance is directly linked to the assumed emission scenario and the considered future simulation periods. The largest changes are projected by 2090 assuming the A1B scenario, then A1B_2050 and finally B1_2050. This occurs both at the annual scale and at the seasonal and monthly scale.

By comparing individual years of the control and scenario periods, it is clear that melting will dramatically increase in future years in summer, even if the snow water equivalent accumulated at the end of the previous winter season is similar.

In 2001 snowfall was exceptionally high, resulting in a slightly positive simulated mass balance. In shifting year 2001 according to the $\Delta$-change signal for scenario B1_2050, the winter accumulation increases further. This projection shows again a positive balance, but is now lower than the control period (Fig. 7); any other scenario shows a negative balance even for the shifted 2001. This agrees with results showing that for most glaciers an increase in accumulation by $40-50 \%$ would be necessary to offset the effect of a temperature increase by $1{ }^{\circ} \mathrm{C}[2,63]$. This behaviour is also consistent with outputs of PDSLIM runs, according to the following equation which was derived through a multiple linear regression analysis:

$b=-1258-473 T_{J J A}+1.123\left(b_{w}+P\right)$

where $b(\mathrm{~mm})$ is the mean annual specific mass balance, $T_{J J A}\left({ }^{\circ} \mathrm{C}\right)$ is the summer temperature from June to August, $b_{w}(\mathrm{~mm})$ is the winter balance, $P(\mathrm{~mm})$ is the precipitation during the melting season. This equation explains $75 \%$ of the variance of the simulated annual mass balance on the Mandrone glacier [69].

Shifting the meteorological data of 2003 (the one with the hottest summer ever registered in the last century) according to A1B 2090 would double the mass loss for the specific year (Figs. 6 and 7). Summer 2008 and 2009 led to negative mass balances as well, as a result of the combination of all the meteorological and glaciological variables; in future scenarios these losses would be even higher than the one foreseen for 2003.

A strong correlation between an increase in the air temperature and the acceleration in the melting process is evident, as shown in Fig. 8 reporting the 20-year average temperature at $3020 \mathrm{~m}$ a.s.l. 
Table 3

Annual and seasonal mass balance (mm w.e.) on the actual size of the Mandrone glacier for control (in bold) and climate change scenarios (maps are shown in Fig. 9).

\begin{tabular}{|c|c|c|c|c|c|c|c|c|c|c|c|c|c|c|c|}
\hline \multirow[t]{2}{*}{ Year } & \multicolumn{5}{|c|}{ Winter mass balance } & \multicolumn{5}{|c|}{ Summer mass balance } & \multicolumn{5}{|c|}{ Annual mass balance } \\
\hline & $\begin{array}{l}\text { Control } \\
\text { run }\end{array}$ & $\begin{array}{l}\text { B1 } \\
2050\end{array}$ & $\begin{array}{l}\text { B1 } \\
2090\end{array}$ & $\begin{array}{l}\text { A1B } \\
2050\end{array}$ & $\begin{array}{l}\text { A1B } \\
2090\end{array}$ & $\begin{array}{l}\text { Control } \\
\text { run }\end{array}$ & $\begin{array}{l}\text { B1 } \\
2050\end{array}$ & $\begin{array}{l}\text { B1 } \\
2090\end{array}$ & $\begin{array}{l}\text { A1B } \\
2050\end{array}$ & $\begin{array}{l}\text { A1B } \\
2090\end{array}$ & $\begin{array}{l}\text { Control } \\
\text { run }\end{array}$ & $\begin{array}{l}\text { B1 } \\
2050\end{array}$ & $\begin{array}{l}\text { B1 } \\
2090\end{array}$ & $\begin{array}{l}\text { A1B } \\
2050\end{array}$ & $\begin{array}{l}\text { A1B } \\
2090\end{array}$ \\
\hline 1995 & 658 & 896 & 773 & 632 & 709 & -1187 & -1721 & -3142 & -2192 & -4267 & -529 & -825 & -2369 & -1560 & -3558 \\
\hline 1996 & 642 & 875 & 755 & 616 & 692 & -754 & -1236 & -2759 & -1854 & -3766 & -112 & -361 & -2004 & -1238 & -3074 \\
\hline 1997 & 711 & 967 & 835 & 683 & 766 & -2475 & -3166 & -4866 & -3660 & -6654 & -1764 & -2199 & -4031 & -2977 & -5888 \\
\hline 1998 & 620 & 844 & 729 & 596 & 668 & -1727 & -2140 & -3670 & -2801 & -4745 & -1107 & -1296 & -2941 & -2205 & -4077 \\
\hline 1999 & 545 & 744 & 642 & 524 & 588 & -1667 & -2455 & -4089 & -3067 & -5258 & -1122 & -1711 & -3447 & -2543 & -4670 \\
\hline 2000 & 537 & 728 & 629 & 516 & 578 & -1948 & -2921 & -5503 & -3930 & -7268 & -1411 & -2193 & -4874 & -3414 & -6690 \\
\hline 2001 & 1458 & 1978 & 1710 & 1402 & 1570 & -1139 & -1687 & -3159 & -2380 & -4757 & 319 & 291 & -1449 & -978 & -3187 \\
\hline 2002 & 323 & 437 & 378 & 311 & 347 & -2051 & -2798 & -4691 & -3536 & -6071 & -1728 & -2361 & -4313 & -3225 & -5724 \\
\hline 2003 & 601 & 812 & 704 & 578 & 646 & -3651 & -4461 & -6411 & -5096 & -7890 & -3050 & -3649 & -5707 & -4518 & -7244 \\
\hline 2004 & 1022 & 1388 & 1200 & 983 & 1101 & -2874 & -3681 & -5978 & -4489 & -7802 & -1852 & -2293 & -4778 & -3506 & -6701 \\
\hline 2005 & 323 & 445 & 382 & 309 & 349 & -2056 & -2825 & -4606 & -3594 & -5713 & -1733 & -2380 & -4224 & -3285 & -5364 \\
\hline 2006 & 640 & 871 & 753 & 615 & 690 & -2025 & -2873 & -4881 & -3654 & -6170 & -1385 & -2002 & -4128 & -3039 & -5480 \\
\hline 2007 & 309 & 417 & 362 & 297 & 332 & -1741 & -2789 & -4856 & -3608 & -6249 & -1432 & -2372 & -4494 & -3311 & -5917 \\
\hline 2008 & 582 & 787 & 681 & 560 & 626 & -3606 & -4670 & -6701 & -5477 & -8287 & -3024 & -3883 & -6020 & -4917 & -7661 \\
\hline 2009 & 1172 & 1585 & 1373 & 1128 & 1262 & -2829 & -3851 & -6074 & -4672 & -7952 & -1657 & -2266 & -4701 & -3544 & -6690 \\
\hline Average & 676 & 918 & 794 & 650 & 728 & -2115 & -2885 & -4759 & -3601 & -6190 & -1439 & -1967 & -3965 & -2951 & -5462 \\
\hline
\end{tabular}

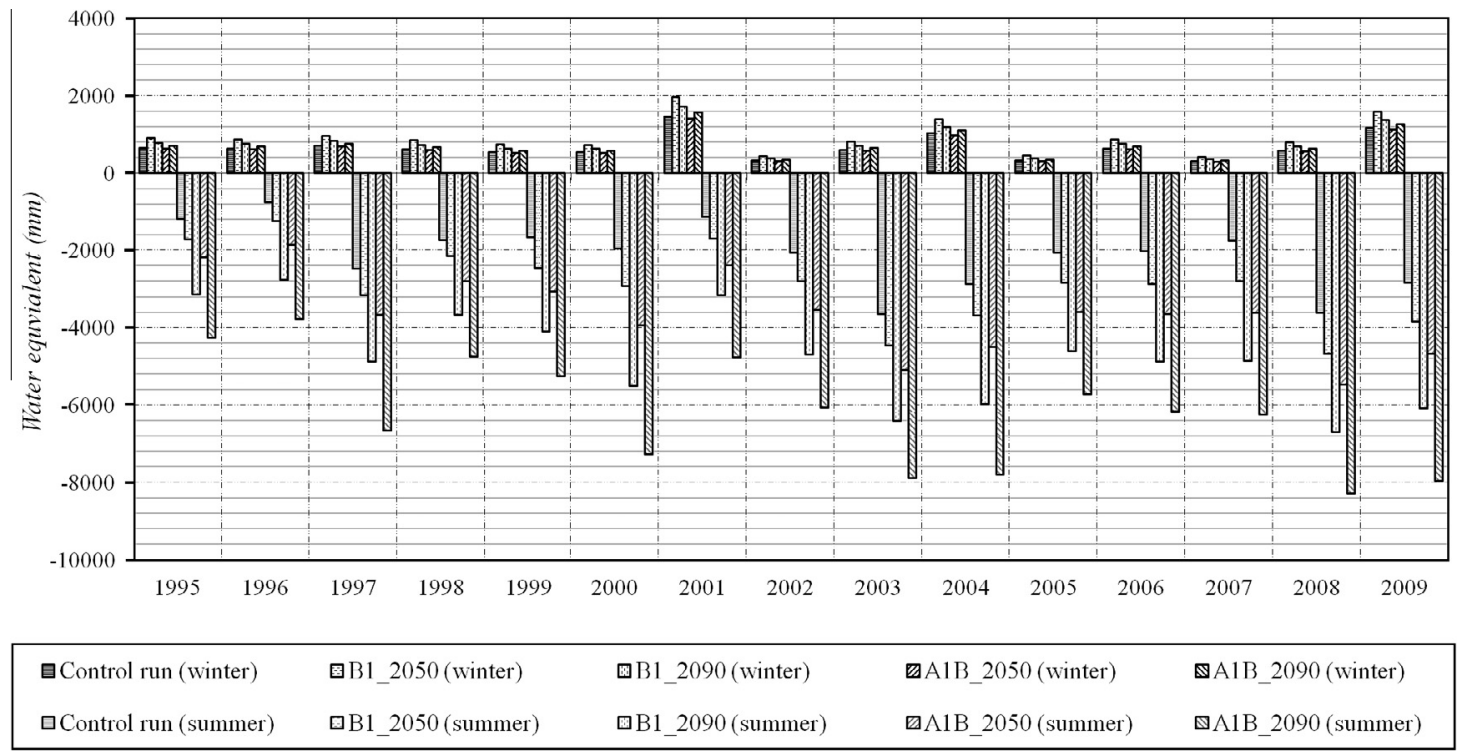

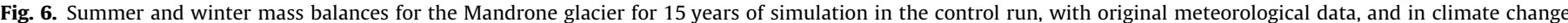
scenarios, obtained by projecting each observation year to future simulation periods.

(Passo della Lobbia), both observed and derived by CLM runs, together with the estimate of the annual mass balances, in the control and climate change scenarios. As the figure outlines, even on a monthly scale the correlation between average air temperature and mass balance is strong, both for the control and scenario runs. The figure shows also that the CLM control run underestimates temperatures at the $3020 \mathrm{~m}$ a.s.l. (in April and May simulated temperature is up to $4{ }^{\circ} \mathrm{C}$ lower than the observed 1995-2009 one at Passo della Lobbia). Also taking into account the non perfect overlapping of the observed and simulated period, the comparison in the summer months is not satisfactory. For this reason the $\Delta$-method was applied to the actual observed climatic regime. Only scenario B1_2050 shows both in April and in May a similar behaviour to that observed in the last 15 years, which means the monthly balance is almost steady. On the other hand in any of the remaining scenarios spring melt starts earlier. Starting from June the discrepancy in mass loss between control and climate change results becomes more pronounced. In some years of scenario A1B_2090 the mass loss in September is comparable to the one in August (as it already occurred in some recent years); this is not true for the majority of remaining years, when mass loss in September is lower because the cold season starts.

The considerations stated so far refer to the whole glacier in order to keep, firstly, a constant spatial domain of the analysis and to investigate only the effects of climate change. The distributed hydrological modelling framework enables also the analysis of the spatial variability of the mass balance (Fig. 9). According to the four scenarios, no positive mass balance will occur in any part of the glacier. As a matter of fact even in the 15 years of the control simulation only $2 \%$ of the whole area shows a positive balance. In 2090, point mass balance is expected to be lower than $-1000 \mathrm{~mm}$ year $^{-1}$ at any location. More moderate losses are shown in the A1B_2050 simulation for a small area on the slopes of Monte Fumo and Dosson di Genova and in the B1_2050 scenario for north-facing slopes.

Even if important uncertainties are included in the PDSLIM algorithm, those included in the CLM model should not be forgotten. Fig. 3 shows the precipitation regime evaluated for the Oglio 


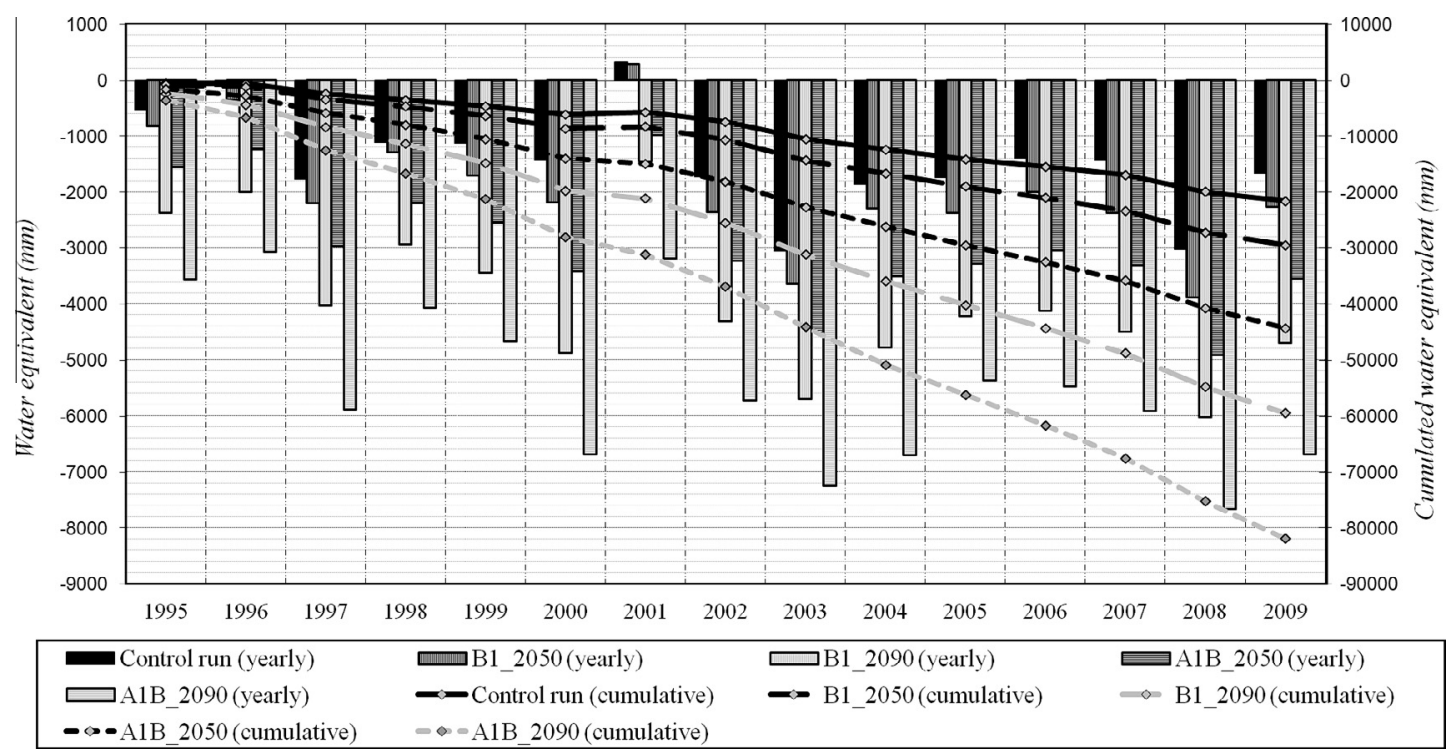

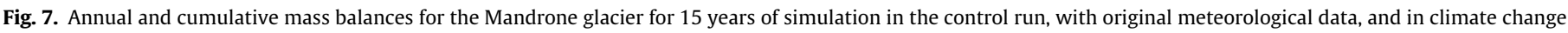
scenarios, obtained by projecting each observation year to future simulation periods.

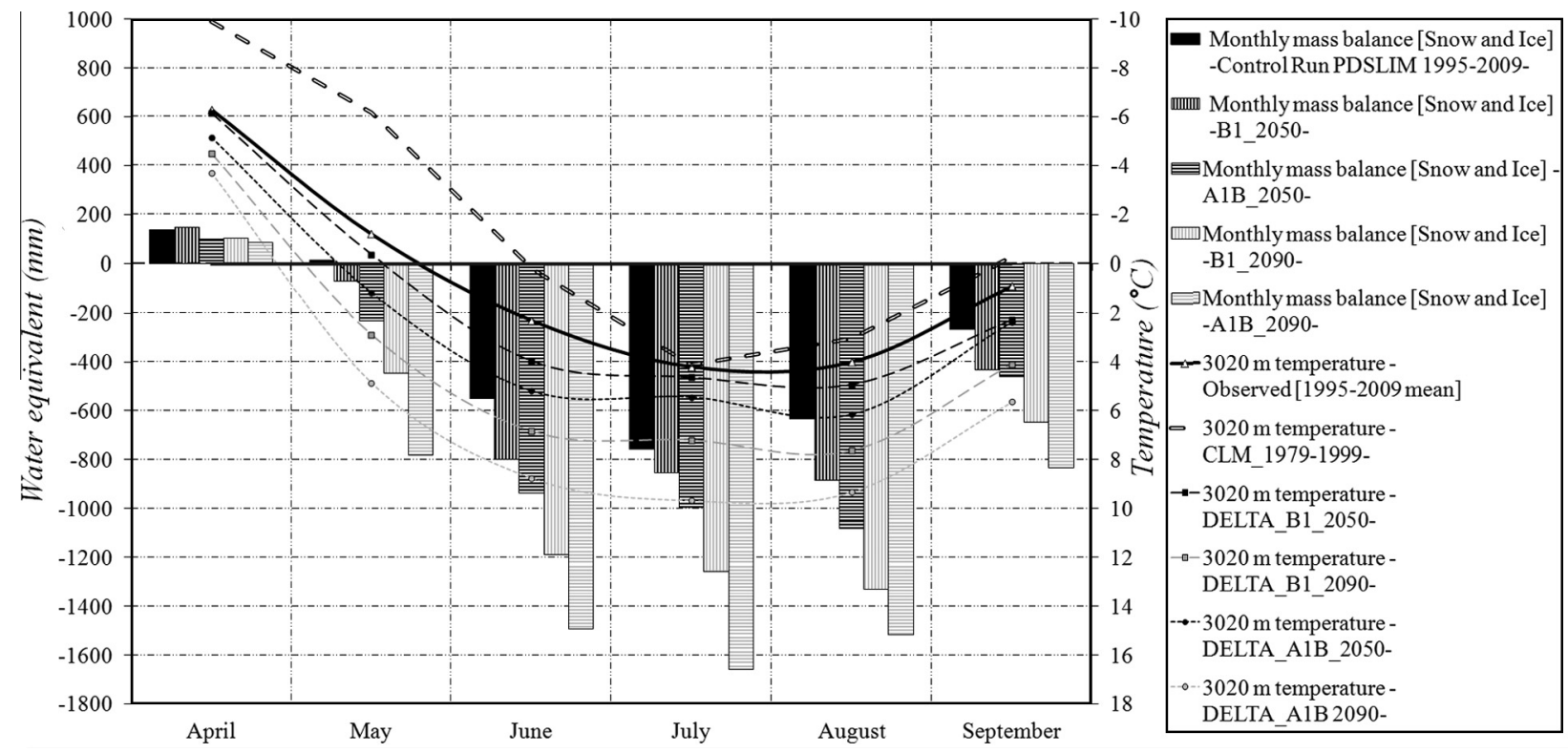

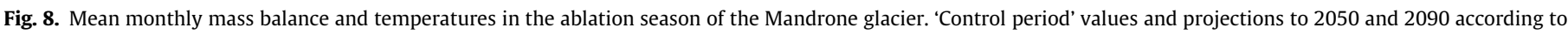
the scenarios A1B and B1 are shown. Observed and projected air temperatures are referred to the Passo della Lobbia Alta altitude at $3020 \mathrm{~m}$ a.s.l.

river basin on the basis of observed precipitation for the period 1979-99 and of CLM output for each climate change scenario. Monthly precipitation is underestimated in summer and overestimated in winter. Considering also the uncertainties in temperature CLM-simulations outlined in Fig. 8, it can be argued that scenarios A1B and B1_2090 are affected by large uncertainties.

As different climate models and socio-economic scenarios result in highly variable meteorological predictions, we also compared the average mass balance obtained by applying the multiple-linear regression equation (7) using temperature and precipitation predictions by three global climate models (GCMs), already investigated for the Adamello glacier area in [9]. In this way we obtained in Table 4 ranges of inter-model and interscenario mass balance simulation, which are an estimate of the degree of 'uncertainty' of mass balance projections depending on the climate forcing adopted: even if B2 and A2 scenarios were not used to simulate the mass balance with PDSLIM, they indicate a high range of temperature predictions for the same scenario. Resulting mass balances ranges are up to $1.4 \mathrm{~m} \mathrm{year}^{-1}$ for the 2050 scenarios and $2.9 \mathrm{~m} \mathrm{year}^{-1}$ for the 2090 scenarios. Similarly, other authors (see [27] e.g.) used ensemble GCMs and RCMs and a distributed temperature-index approach to project runoff evolution in nine high Alpine Swiss catchments.

Despite large uncertainties it is still not possible to exclude the possibility that the temperature will increase so much by the end of the 21st century. If emission thresholds will be reached by pessimistic socio-economic and technological scenarios, then such a dramatic response of the glacier should be considered as realistic. 


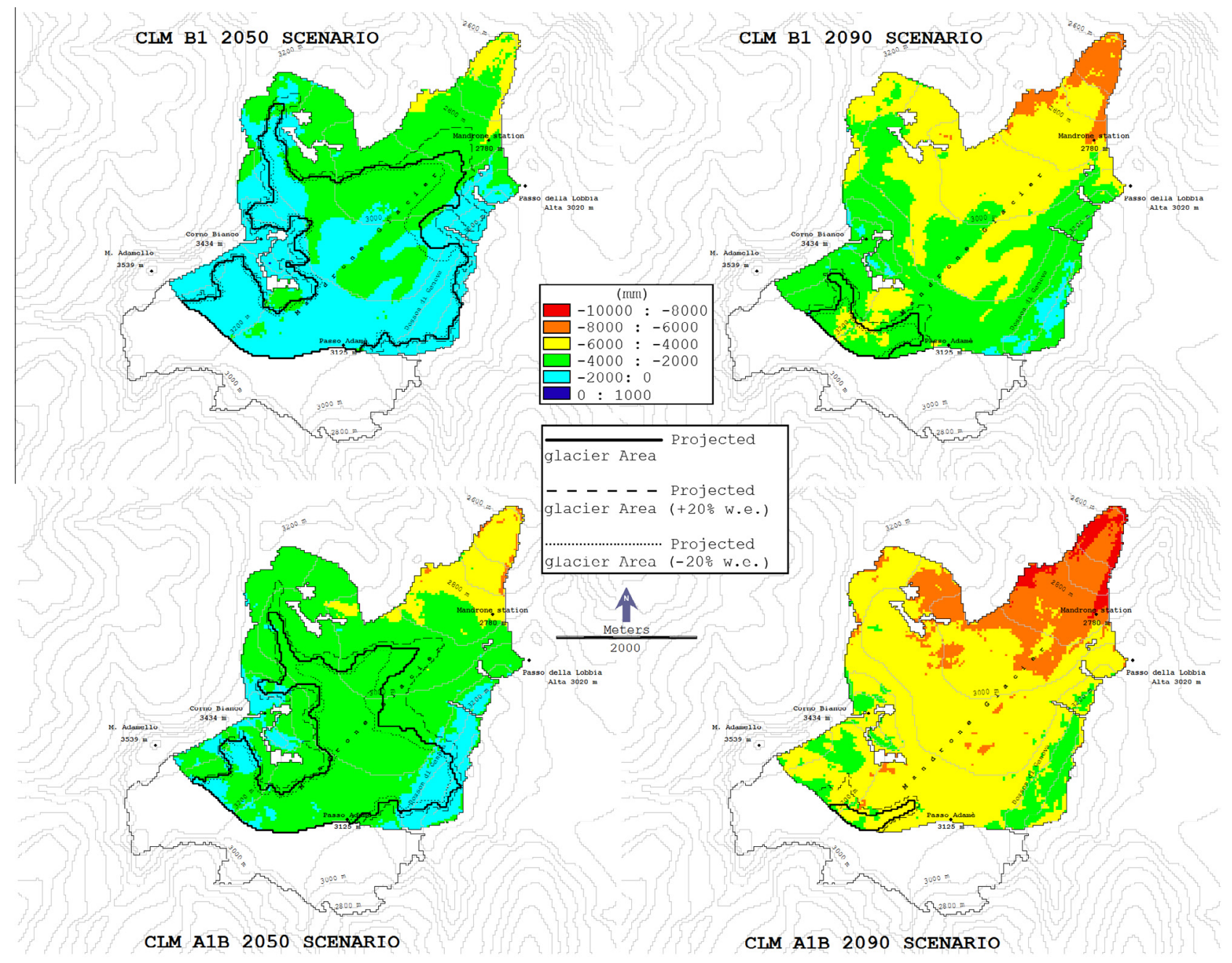

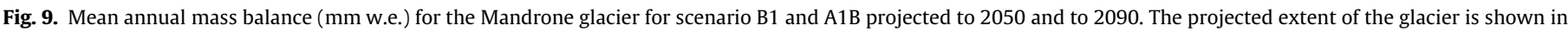
black continuous line. Dashed lines represent the extent assuming a $\pm 20 \%$ mass balance standard uncertainty.

Table 4

Comparison of summer temperatures at $3020 \mathrm{~m}$ a.s.l., summer and winter semester precipitation and mean annual mass balance for the Mandrone glacier projected to 2050 and 2090 by different scenarios and different climate models.

\begin{tabular}{lrlllc}
\hline $\begin{array}{l}\text { Climate model and } \\
\text { scenario }\end{array}$ & $\begin{array}{c}T_{J J A} \\
\left({ }^{\circ} \mathrm{C}\right)\end{array}$ & $\begin{array}{l}P_{\text {summer }} \\
(\mathrm{mm})\end{array}$ & $\begin{array}{l}P_{\text {winter }} \\
(\mathrm{mm})\end{array}$ & $\begin{array}{l}b_{\text {annual }} \\
(\mathrm{mm})\end{array}$ & $\begin{array}{c}\text { Range } \\
(\mathrm{mm})\end{array}$ \\
\hline PCM_B2_2050 & 4.4 & 797 & 670 & -1676 & \\
ECHAM_B2_2050 & 6.7 & 781 & 697 & -2751 & 1322 \\
HADCM_B2_2050 & 7.0 & 724 & 690 & -2998 & \\
PCM_A2_2050 & 4.5 & 815 & 682 & -1690 & \\
ECHAM_A2_2050 & 7.0 & 761 & 638 & -2981 & 1387 \\
HADCM_A2_2050 & 7.1 & 736 & 650 & -3077 & \\
PCM_B2_2090 & 5.2 & 775 & 668 & -2081 & \\
ECHAM_B2_2090 & 8.2 & 773 & 711 & -3470 & 1981 \\
HADCM_B2_2090 & 9.2 & 677 & 701 & -4062 & \\
PCM_A2_2090 & 6.0 & 782 & 692 & -2440 & \\
ECHAM_A2_2090 & 11.1 & 753 & 671 & -4925 & 2889 \\
HADCM_A2_2090 & 11.6 & 653 & 622 & -5330 & \\
PCM_A1B_2090 & 5.8 & 747 & 754 & -2315 & \multirow{2}{*}{ (2043 } \\
CLM_A1B_2090 & 9.2 & 585 & 727 & -4158 & 1843
\end{tabular}

\subsection{Evolution of the shape of the Mandrone glacier}

An analysis of the evolution of the extension of the glacier was also performed, in order to predict the future areal extent of the
Mandrone glacier and to re-evaluate the mass balance on the future glacier surface according to each of the four scenarios. In this analysis the combined effect of both the climate change impact on the mass balance and the resulting morphological adaptation of the glacier is taken into account with a simplified approach, as done for instance by Huss et al. [33], who first calculated the change in glacier surface elevation and area through a simple parameterization and then applied an ice-flow model. Considering the additive and multiplicative correction factors listed in Table 2, a linear change of temperature and precipitation over the 20102050 and 2050-2090 periods was assumed. Eq. (7) was then applied to compute the glacier mass balance for each year in the two time periods in-between the control period and the future climate change scenarios. Cumulated mass balances in the 20102050 and 2010-2090 periods were: B1_2050 $=-57 \mathrm{~m}$ w.e., B1 $\_2090=-178 \mathrm{~m}$ w.e., $\quad$ A1B_2050 $=-77 \mathrm{~m}$ w.e., $\quad$ A1B_2090 $=$ $-221 \mathrm{~m}$ w.e.

The spatial variability of the mass balance in each year of the two in-between periods was assessed by normalizing the mass balance maps shown in Fig. 9 for each scenario simulation and multiplying them by the respective annual mass balance in the intermediate period.

The annual mass loss was then subtracted from the glacier thickness estimated for the Adamello glacier by ARPA-Lombardia [16] by combining aerial and topographic surveys, IKONOS satellite 
images over the 1985-2007 period and georadar surveys conducted in 1997-1998 [28]. Resulting positive ice depths contribute to the surviving mass of the glacier for each scenario.

Survived areas were then modified by considering the glacier flow velocity estimated from the simplified ice flow model described in Section 3.4. The cumulated mass losses computed in each grid cell from 2010 to 2050 and 2090 projected years was subtracted to the actual glacier's volume, and then combined with the effect of the ice flow. To estimate the average velocity for the Mandrone glacier an ice slab with a thickness between the actual condition and the future projections was considered. For example, for the B1_2050 scenario we obtained a thickness decrease of $50 \mathrm{~m}$, from the actual $100 \mathrm{~m}$ to the future $50 \mathrm{~m}$, on the central part of the glacier. Considering Eq. (6), with a slope of $10^{\circ}$ corresponding to the mean slope on the central part of the Mandrone glacier, a value ranging from 16 to $32 \mathrm{~m}_{\text {year }}{ }^{-1}$ was obtained and used to shift downstream the boundaries resulting from pure mass balance. A glacier's size of 7.1 and $4.6 \mathrm{~km}^{2}$ according to the B1_2050 and A1B_2050 scenarios was obtained, respectively. Updated masks where then used to project mass balance according to the A1B and B1 scenarios.

Resulting boundaries of the glacier are shown in Fig. 9 for each scenario: continuous lines show the expected shape, dashed and dotted lines show the predicted shape with the assumption of a standard uncertainty of $+20 \%$ and $-20 \%$, respectively, on the cumulative mass balance. This result is consistent with surveys in the 1985-2007 period. Computed annual glacier mass balances on the updated boundaries are listed in Table 5, showing, on average, a $10 \%$ change with respect to the actual size domain.

\subsection{Comparison with surrounding glaciers: Caresèr and Presena}

Results of the analysis on the Mandrone glacier are in agreement with the above mentioned findings concerning the Caresèr glacier mass balance obtained with the glaciological method ( $-1686 \mathrm{~mm}$ w.e. year $^{-1}$ in the $1995-2009$ period). In Table 6 mass balances estimated by PDSLIM simulations applied to the Presena glacier are also presented, resulting in an estimated specific mass balance in the 1995-2009 period of $-1503 \mathrm{~mm}$ w.e. year $^{-1}$. The results for these two glaciers are in agreement with the Mandrone glacier mass loss $\left(-1439 \mathrm{~mm}\right.$ w.e. year $\left.{ }^{-1}\right)$, considering the different size, altitude and aspect of the three glaciers, as described in Section 2.1.

Table 5

Annual mass balance ( $\mathrm{mm}$ w.e.) on the projected size of the Mandrone glacier for the control run (in bold) and four climate change scenarios (maps are shown in Fig. 9).

\begin{tabular}{|c|c|c|c|c|c|}
\hline \multirow[t]{2}{*}{ Year } & \multicolumn{5}{|c|}{ Annual mass balance } \\
\hline & Control run & B1 2050 & B1 2090 & A1B 2050 & A1B 2090 \\
\hline 1995 & -529 & -659 & -1727 & -1310 & -3021 \\
\hline 1996 & -112 & -186 & -1601 & -1056 & -2731 \\
\hline 1997 & -1764 & -1982 & -3348 & -2630 & -5359 \\
\hline 1998 & -1107 & -1134 & -2413 & -1984 & -3626 \\
\hline 1999 & -1122 & -1504 & -2970 & -2272 & -4256 \\
\hline 2000 & -1411 & -1895 & -4254 & -3020 & -6132 \\
\hline 2001 & 319 & -69 & -1064 & -799 & -2834 \\
\hline 2002 & -1728 & -2115 & -3747 & -2915 & -5287 \\
\hline 2003 & -3050 & -3366 & -5158 & -4166 & -6803 \\
\hline 2004 & -1852 & -2024 & -4121 & -3154 & -6243 \\
\hline 2005 & -1733 & -2125 & -3637 & -2961 & -4892 \\
\hline 2006 & -1385 & -1741 & -3475 & -2696 & -4963 \\
\hline 2007 & -1432 & -2095 & -3834 & -2950 & -5422 \\
\hline 2008 & -3024 & -3565 & -5243 & -4534 & -7048 \\
\hline 2009 & -1657 & -1976 & -4003 & -3180 & -6120 \\
\hline Average & -1439 & -1762 & -3373 & -2642 & -4982 \\
\hline
\end{tabular}

Table 6

Annual mass balance of three glaciers in the investigated region.

\begin{tabular}{llcr}
\hline \multirow{2}{*}{ Year } & \multicolumn{2}{c}{ Annual mass balance $(\mathrm{mm})$} & \\
\cline { 2 - 4 } & Mandrone $^{\mathrm{a}}$ & Presena $^{\mathrm{a}}$ & Caresèr $^{\mathrm{b}}$ \\
\hline 1995 & -529 & -496 & -1081 \\
1996 & -112 & -219 & -1320 \\
1997 & -1764 & -1504 & -920 \\
1998 & -1107 & -1088 & -2240 \\
1999 & -1122 & -1314 & -1800 \\
2000 & -1411 & -1888 & -1610 \\
2001 & 319 & -106 & -250 \\
2002 & -1728 & -1582 & -1149 \\
2003 & -3050 & -2502 & -3317 \\
2004 & -1852 & -1972 & -1562 \\
2005 & -1733 & -1675 & -2005 \\
2006 & -1385 & -1453 & -2169 \\
2007 & -1432 & -1606 & -2783 \\
2008 & -3024 & -3087 & -1851 \\
2009 & -1657 & -2053 & -1235 \\
Average & -1439 & -1503 & -1686 \\
\hline
\end{tabular}

a Energy and mass balance simulation in the present study.

b Years 1995-2006 [17]; year 2007 [8]; years 2008 and 2009 (Carturan, personal communication).

It must be pointed out that simulated summer mass balances are affected by major uncertainties regarding measurements of precipitation and air temperature at high altitude, as reported for instance by Ranzi et al. [68] and Huwald et al. [35].

Up-to-date predicted changes in air temperature in the regional climate are higher than those obtained in the early nineties for the Caresèr glacier based on the pioneering Goddard Institute for Space Studies (GISS) projections and their effects are expected to be more dramatic on the glaciers' mass balances [4,31].

\section{Conclusions}

In this work a physically based modelling approach was adopted to evaluate the mass balance of the Mandrone glacier, the largest branch of the Adamello-Presanella mountain group in the Italian Alps. Its specific mass balance in actual conditions $\left(-1439 \mathrm{~mm}\right.$ w.e. year $\left.^{-1}\right)$ is in agreement with that of the nearby Presena and Caresèr glaciers and will become much more negative as a result of the climate scenarios projected by the CLM regional model, indicating a high vulnerability of the volume and area of Alpine glaciers in this area to climate change.

Although the modelling results in the current conditions are still uncertain, mainly due to errors in precipitation measurements at high altitude and the hypotheses of the energy balance model adopted, verifications with point ablation measurements and satellite-derived snow cover were performed with satisfactory results. Climate projections are uncertain as well but new generation regional climate models like CLM are quite consistent in indicating a strong temperature increase in high mountain areas.

The average annual mass loss over a 15-year time window (1995-2009) projected to different future emission scenarios (B1 and $\mathrm{A} 1 \mathrm{~B})$ shows further acceleration of the Mandrone glacier retreat in the 21st century. In 2050 for the B1 scenario the specific annual mass balance will be about $-2000 \mathrm{~mm}$ w.e., while for A1B scenario it will be $-3000 \mathrm{~mm}$ w.e. Looking right at the end of the 21st century, for the A1B scenario $-5500 \mathrm{~mm}$ w.e. was obtained, while for the B1 scenario $-4000 \mathrm{~mm}$ w.e. was obtained. These results are obtained assuming a constant computational domain corresponding to the actual glacier size. They change by about $10 \%$ when the glacier's area retreat is computed on the basis of a simplified model of volume change and ice flow. The areal reduction projected to 2050 ranges between $45 \%$ and $65 \%$ of the actual 
$13.4 \mathrm{~km}^{2}$ size, according to the B1 and A1B scenario, respectively. Most of the ice will have melted away by the end of the century.

Taking into account both the current abrupt retreat of the studied glaciers (and of several others in the Alps) and the obtained results on future scenarios, it is possible to draw important notes on the glaciers' response to climate change. Leaving apart the uncertainty of the model results, the retreat of the Alpine glaciers is more and more evident and at the moment there is no evidence of a trend inversion.

In perspective of future research development, it is worth investigating the positive feedback due to enhanced radiative heating from surrounding rocks, which is expected to even accelerate the glacier retreat, as noticed for the Caresèr glacier. A negative feedback, however, could result from a debris layer covering the ice. More detailed coupled mass balance-ice flow models should be used to better assess the geomorphological adaptation of glaciers to the projected mass losses.

\section{Acknowledgments}

This research was funded by the PRIN 2008 Grant and by Fondazione CARIPLO within the research project "CARIPANDA" coordinated by Parco dell'Adamello. Parco Adamello-Brenta is gratefully acknowledged for having authorized the installation of the meteorological station of the University of Brescia at Passo della Lobbia Alta. Meteorological and runoff data were available thanks to ENEL, Meteotrentino, Provincia Autonoma di Trento (Servizio Opere Idrauliche) and Arpa Lombardia. CLM data were kindly made available for our research by WDCC (http://www.mad.zmaw.de/wdcfor-climate/index.html). Stefan Taschner, Alessandro Gitti, Laura Bruschi and several students and mountain guides are thanked for their support during our field surveys over 8 years: their enthusiasm and help motivated and supported our work. Three anonymous reviewers are thanked for their useful comments and suggestions.

\section{References}

[1] Alcamo J, Moreno JM, Novaky B, Binfi M, Corobov R, Devoy RJN, et al. In: Parry ML, Canziani OF, Palutikof JP, Van der Linden PJ, Hanson CE, editors. Europe, climate change 2007. Impacts, adaptation and vulnerability, contribution of working group II to the fourth assessment report of the intergovernmental panel on climate change. Cambridge, UK: Cambridge University Press; 2007. p. 541-80.

[2] Alley RB. Comment on "When earth's freezer door is left ajar". EOS (Trans Am Geophys Union) 2003;84:315.

[3] Auer I, Böhm R, Jurkovic A, Lipa W, Orlik A, Potzmann R. HISTALP - historical instrumental climatological surface time series of the Greater Alpine Region. Int J Climatol 2007;27:17-46.

[4] Bach W. In: Projected climatic changes and impacts in Europe due to increased $\mathrm{CO}_{2} ; 1989$. p. 31-50.

[5] Bárdossy A, Anagnostopoulou C, Cacciamani C, Caspary H, Frei C, Goodess C et al. Trends in extreme daily precipitation and temperature across Europe in the 2nd half of the 20th century. Deliverable D9 of STARDEX project: STAtistical and Regional dynamical Downscaling of EXtremes for European regions; 2003.

[6] Baroni C, Carton A. Variazioni oloceniche della Vedretta della Lobbia (Gruppo dell'Adamello Alpi Centrali). Geogr Fis Din Quat 1990;13:105-19 [in Italian].

[7] Baroni C, Carton A. Geomorfologia dell'alta Val di Genova (Gruppo dell'Adamello Alpi Centrali). Geogr Fis Din Quat 1996;19:3-17 [in Italian].

[8] Baroni C, Meneghel M, Mortara G. Report of the glaciological survey 2009 (CGI - Italian Glaciological Committee). Geogr Fis Din Quat 2010;33(2).

[9] Barontini S, Grossi G, Kouwen N, Maran S, Scaroni P, Ranzi R. Impacts of climate change scenarios on runoff regimes in the southern Alps. Hydrol Earth Syst Sci Discuss 2009;6:3089-141.

[10] Beniston M, Jungo P. Shifts in the distributions of pressure, temperature and moisture and changes in the typical weather patterns in the alpine region in response to the behaviour of the North Atlantic Oscillation. Theor Appl Climatol 2002;71:29-42.

[11] Bernhardt M, Schulz K. SnowSlide: a simple routine for calculating gravitational snow transport. Geophys Res Lett 2010;37(L11502):1-6.

[12] Brunetti M, Lentini G, Maugeri M, Nanni T, Auer I, Böhm R, et al. Climate variability and change in the Great Alpine Region over the last two centuries based on multi-variable analysis. Int J Climatol 2009;29(15):2197-225.
[13] Cagnati A, Crepaz A, Macelloni G, Pampaloni P, Ranzi R, Tedesco M. Study of the snow meltfreeze cycle using multi-sensor data and snow modelling. J Glaciol 2004;50(170):419-26.

[14] Calmanti S, Motta L, Turco M, Provenzale A. Impact of climate variability on Alpine glaciers in northwestern Italy. Int J Climatol 2007;27:2041-53.

[15] Carabelli E. Misure sismiche di spessore del ghiacciaio Pian di Neve (Adamello). Boll Com Glaciol Italiano 1961;serie 2, 11(1):51-60 [in Italian].

[16] CARIPANDA (CAmbio climatico e RIsorsa idrica nel PArco Naturale dell'ADAmello). Relazione finale. 2010. 272 p. [in Italian].

[17] Carturan L, Seppi R. Recent mass balance results and morphological evolution of Careser Glaciers (Central Alps). Geogr Fis Din Quat 2007;30(1):33-42.

[18] Citterio M, Diolaiuti G, Smiraglia C, D'agata C, Carnielli T, Stella G, et al. The fluctuations of Italian glaciers during the last century: a contribution to knowledge about Alpine glacier changes. Geogr Annal 2007;89(A3):164-82.

[19] ClimChAlp. Interreg III b Alpine Space, Work Package 5. Climate Change Assessment Report: responsible S. Castellari (CMCC/INGV, Italy); 2008

[20] Colbeck SC. An analysis of water flow in dry snow. Water Resour Res 1976; 12(3):523-7.

[21] Coppola A, Leonelli G, Salvatore MC, Pelfini M, Baroni C. Weakening climatic signal since mid-20th century in European larch tree-ring chronologies at different altitudes from the Adamello-Presanella Massif (Italian Alps). Quat Res 2012;77:344-55.

[22] Dadic R, Mott R, Lehning M, Burlando P. Wind influence on snow depth distribution and accumulation over glaciers. J Geophys Res 2010;115(F01012): $1-8$.

[23] Diolaiuti G, Smiraglia C, Reynaud L, D'agata C, Pavan M. Relation entre les bilans de masse de la Sforzellina et ceux des autres glaciers en Europe, Influence des facteurs localisation géographique et taille du glacier. La Houille Blanche 2002;6/7:1-5.

[24] EEA. Impacts of Europe's changing climate. 2008 indicator-based assessment EEA Report No: 4/2008, JRC Reference Report No: JRC47756. Copenhagen, Denmark: European Environment Agency; 2008.

[25] EEA. Regional climate change and adaptation: the Alps facing the challenge of changing water resources. Report No:8/2009. Copenhagen, Denmark: European Environment Agency; 2009.

[26] European Parliament and Council. Regulation of the European Parliament and of the Council. Official Journal of the European Union L149. May 23 2007; (EC) No. 614/2007.

[27] Farinotti D, Usselmann S, Huss M, Bauder A, Funk M. Runoff evolution in the Swiss Alps: projections for selected high-alpine catchments based on ENSEMBLES scenarios. Hydrol Processes 2012;26:1909-24.

[28] Frassoni A, Rossi GC, Tamburini A. Studio del ghiacciaio dell'Adamello mediante indagini georadar. Suppl Geogr Fis Din Quat 2001;5:77-84 [in Italian].

[29] Giada M, Zanon G. Elevation and volume changes in the Careser glacier (OrtlesCevedale group, Central Alps). Z Gletscherkunde Glazialgeol 1996;31:143-7.

[30] Groppelli B, Bocchiola D, Rosso R. Spatial downscaling of precipitation from GCMs for climate change projections using random cascades: a case study in Italy. Water Resour Res 2011;47:W03519.18.

[31] Grossi G. Vulnerabilità di un serbatoio di regolazione nelle ipotesi di cambiamento climatico. Degree thesis in Civil Engineering. University of Parma. 1992 [in Italian].

[32] Haeberli W. Glacier fluctuations and climate change detection - operational elements of a worldwide monitoring strategy. Bull World Meteorol Organiz 1995;44:23-31.

[33] Huss M, Jouvet G, Farinotti D, Bauder A. Future high-mountain hydrology: a new parameterization of glacier retreat. Hydrol Earth Syst Sci 2010;14: 815-29.

[34] Hutter K. Theoretical glaciology. Dordrecht: Kluwer Academic Publishers; 1983. $548 \mathrm{p}$

[35] Huwald H, Higgins CW, Boldi MO, Bou-Zeid E, Lehning M, Parlange MB. Albedo effect on radiative errors in air temperature measurements. Water Resour Res 2009;45(8):1-13.

[36] IAHS(ICSI)/UNEP/UNESCO. Fluctuations of the glaciers, 1990-95. In: Haeberli W, Hoelzle M, Suter S, Frauenfelder R, editors. World Glacier Monitoring Service, University and ETH, Zurich; 1998.

[37] IAHS(ICSI)/UNEP/UNESCO. Glacier mass balance bulletin no. 5. In: Haeberli W, Hoelzle M, Suter S, Frauenfelder R, editors. World Glacier Monitoring Service, University and ETH, Zurich; 1999.

[38] IPCC. In: Houghton JT, Jenkins GJ, Ephraums JJ, editors. Climate change. The IPCC scientific assessment. Report prepared for IPCC by working group I. Cambridge, UK: Cambridge University Press; 1990. 375 p.

[39] IPCC. In: Tegart WJ McG, Sheldon GW, Sheldon GW, Griffiths DC, editors Climate change. The IPCC impacts assessment. Report prepared for IPCC by working group II. Canberra, Australia: Australian Government Publishing Service; $1990.273 \mathrm{p}$.

[40] IPCC. In: Houghton JT, Callander BA, Varney SK, editors. Climate change 1992. The supplementary report to the IPCC scientific assessment. Cambridge, UK: Cambridge University Press; 1992. 198 p.

[41] IPCC. In: Houghton JT, Meira Filho LG, Callander BA, Harris N, Kattenberg A, Maskell K, editors. Climate change 1995. The science of climate change. Contribution of the working group I to the second assessment report of the inter-governmental panel on climate change. New York, USA: Cambridge University Press; 1996. 572 p.

[42] IPCC. In: Watson RT, Zinyowera MC, Moss RH, editors. Climate change 1995. Impacts, adaptations and mitigations of climate change: scientific-technical 
analyses: the second assessment report of the inter-governmental panel on climate change. New York, USA: Cambridge University Press; 1996. 880 p.

[43] IPCC. In: Houghton JT, Ding Y, Griggs DJ, Noguer M, Van der Linden PJ, Dai X, et al., editors. Climate change 2001. The scientific basis. Contribution of working group I to the third assessment report of the intergovernmental panel on climate change. Cambridge, UK, New York, USA: Cambridge University Press; 2001. $881 \mathrm{p}$.

[44] IPCC. In: Parry ML, Canziani OF, Palutikof JP, Van der Linden PJ, Hanson CE editors. Climate change 2007. Impacts, adaptation and vulnerability, contribution of working group II to the fourth assessment report of the intergovernmental panel on climate change. Cambridge, UK: Cambridge University Press; 2007. 976 p.

[45] Italian Ministry of the Environment and the Protection of Land and Sea [Internet]. Rome [updated 2011 Oct 13; cited 2011 Oct 13]. LIFE+ Call for proposals 2011 - National annual priorities for Italy 2011. Available from: http://www.minambiente.it/home_it/menu.html?mp=/menu/menu_attivita/ \&m=LIFE_html|Call_for_proposal_2011.html\&lang=it.

[46] Kaser G, Fountain A, Jansson P. A manual for monitoring the mass balance of mountain glaciers. IHP Tech Doc Hydrol 2003;59:107.

[47] Kaser G, Cogley JG, Dyurgerov MB, Meier MF, Ohmura A. Mass balance of glaciers and ice caps: consensus estimates for 1961-2004. Geophys Res Lett 2006;33(19):1-5

[48] Kuhn M. Climate and glaciers. In: Allison I, editor. Sea level, ice, and climate change, vol. 131. IAHS Publications; 1979. p. 3-20.

[49] Kuhn M, Markl G, Kaser G, Nickus U, Obleitner F, Schneider H. Fluctuations of climate and mass balance: different responses of two adjacent glaciers. Z Gletscherkunde Glazialgeol 1985;21:409-16.

[50] Lehning $M$, Löwe H, Ryser M, Raderschall N. Inhomogeneous precipitation distribution and snow transport in steep terrain. Water Resour Res 2008;44(W07404):1-19.

[51] López-Moreno JI, Goyette S, Beniston M. Impact of climate change on snowpack in the Pyrenees: horizontal spatial variability and vertical gradients. J Hydrol 2009;374:384-96.

[52] Macelloni G, Paloscia S, Pampaloni P, Brogioni M, Ranzi R, Crepaz A Monitoring of melting refreezing cycles of snow with microwave radiometers: the microwave alpine snow melting experiment (MASMEx 2002-2003). IEEE Trans Geosci Remote Sens 2005;43(11):2431-42.

[53] Machguth H, Paul F, Kotlarski S, Hoelzle M. Calculating distributed glacier mass balance for the Swiss Alps from regional climate model output: a methodical description and interpretation of the results. J Geophys Res 2009;114(D19):1-19.

[54] Manzata. A mathematical 2d ice-flow model and its application to a parallelsided ice slab. In: Proceedings XXXIII conference of hydraulics and hydraulic engineering. Cosenza: Edibios; 2012. 10 p. [in Italian]

[55] Maragno D, Diolaiuti G, D’agata C, Mihalcea C, Bocchiola D, Bianchi Janetti E, et al. New evidence from Italy (Adamello Group, Lombardy) for analysing the ongoing decline of Alpine glaciers. Geogr Fis Din Quat 2009;32:31-9.

[56] Marchetti F. Relazioni delle campagne glaciologiche: Ghiacciai del Gruppo Adamello-Presanella. Ghiacciaio del Mandron. Geogr Fis Din Quat 1999-2004. 1999;22(2), 2000;23(2), 2001;24(2), 2002;25(2), 2003;26(2), 2004;27(2) [in Italian].

[57] Marchetti V. Relazioni delle campagne glaciologiche: Gruppo AdamelloPresanella (versante trentino). Ghiacciai della Lobbia e del Mandron. Geogr Fis Din Quat 1978-1993. 1978;1(1), 1979;2(2), 1980;3(2), 1981;4(2) $1982 ; 5(2), \quad 1985 ; 7(2), \quad 1987 ; 9(1), \quad 1988 ; 10(2), \quad 1989 ; 11(2), \quad 1990 ; 12(2)$, $1991 ; 13(2), 1992 ; 14(2), 1993 ; 15$ [in Italian].
[58] Marson I. Sui ghiacciai dell'Adamello-Presanella (alto bacino del SarcaMincio). Boll Com Glaciol Italiano 1906;serie IV, 7(6):546-68 [in Italian].

[59] Nakicenovic N, Alcamo J, Davis G, De Vries B, Fenhann J, Gaffin S, et al. Special report on emissions scenarios: a special report of working group III of the intergovernmental panel on climate change. Cambridge, UK: Cambridge University Press; 2000. 599 p.

[60] Obleitner F, Lehning M. Measurement and simulation of snow and superimposed ice at the Kongsvegen glacier, Svalbard (Spitzbergen). J Geophys Res 2004;109(D4):1-12.

[61] Oerlemans J. Quantifying global warming from the retreat of glaciers. Science 1994;264:243-5.

[62] Oerlemans J, Anderson B, Hubbard A, Huybrechts PH, Hannesson TJ, Knap WH, et al. Modelling the response of glaciers to climate warming. Clim Dyn 1998; $14: 267-74$

[63] Ohmura A, Kasser P, Funk M. Climate at the equilibrium line of glaciers. J Glaciol 1992;38(130):397-411.

[64] Paterson WSB. The physics of glaciers. 3rd ed. Oxford: Pergamon Press; 1994. $480 \mathrm{p}$.

[65] Pomeroy JW, Gray DM. Saltation of snow. Water Resour Res 1990;26(7): 1583-94.

[66] Ranzi R, Rosso R. A physically based approach to modelling distributed snowmelt in a small alpine catchment. In: Bergmann H, Lang H, Frey W, Issler D, Salm B, editors. Snow hydrology and forests in high alpine areas, vol. 205. Wallingford, UK: IAHS Publications; 1991. p. 141-50.

[67] Ranzi R, Rosso R. Distributed estimation of incoming direct solar radiation over a drainage basin. J Hydrol 1995;166:461-78.

[68] Ranzi R, Grossi G, Bacchi B. Ten years of monitoring areal snowpack in the Southern Alps using NOAA-AVHRR imagery, ground measurements and hydrological data. Hydrol Processes 1999;13:2079-95.

[69] Ranzi R, Grossi G, Gitti A, Taschner S. Energy and mass balance of the Mandrone glacier (Adamello, Central Alps). Geogr Fis Din Quat 2010;33:45-60.

[70] Ranzi R, Grossi G, Iacovelli L, Taschner S. Use of multispectral Aster images for mapping debris-covered glaciers within the GLIMS Project. In: 2004 IEEE International Geoscience and Remote Sensing Symposium Proceedings, 2004.

[71] Santilli M, Orombelli G, Pelfini M. Variations of Italian glaciers between 1980 and 1999 inferred by the data supplied by the Italian Glaciological Committee. Geogr Fis Din Quat 2002;25:61-76.

[72] Satterlund DR. An improved equation for estimating long-wave radiation from the atmosphere. Water Resour Res 1979;15(6):1649-50.

[73] Schwitter MP, Raymond CF. Changes in the longitudinal profiles of glaciers during advance and retreat. J Glaciol 1993;39:582-90.

[74] Tangborn WV, Krimmel RM, Meier MF. A comparison of glacier mass balance by glaciological hydrological and mapping methods, South Cascade Glacier. Snow and Ice - Symposium - Neiges et Glaces, vol. 104. Washington: IAHSAISH Publication; 1975. p. 185-96.

[75] Valt M, Cagnati A, Crepaz A. Recent trend of snow precipitation on Italian Alps. AINEVA - Neve e Valanghe 2005;56:24-31 [in Italian].

[76] Weertman J. On the sliding of glaciers. J Glaciol 1957;3:33-8.

[77] Weertman J. The theory of glacier sliding. J Glaciol 1964;5:287-303.

[78] WGMS. Global glaciers changes: facts and figures. In: Zemp M, Roer I, Kääb A Hoelzle M, Paul F, Haeberli W, editors. UNEP, World Glacier Monitoring Service, Zurich, Switzerland; 2008. 88 p.

[79] Zanon G. Venticinque anni di bilancio di massa del ghiacciaio del Careser, 1966-67/1990-91. Geogr Fis Din Quat 1992;15:215-20 [in Italian].

[80] Zemp M, Haeberli W, Hoelzle M, Paul F. Alpine glaciers to disappear within decades? Geophys Res Lett 2006;33(13):1-4. 